\title{
Late Medieval Sculpture from the Church of St. Peter, Tiverton
}

\section{Miss E. K. Prideaux}

To cite this article: Miss E. K. Prideaux (1918) Late Medieval Sculpture from the Church of St. Peter, Tiverton, Archaeological Journal, 75:1, 209-240, DOI: 10.1080/00665983.1918.10853328

To link to this article: http://dx.doi.org/10.1080/00665983.1918.10853328

曲 Published online: 17 Jul 2014.

Submit your article to this journal $\pi$

Џll Article views: 2

Q View related articles $\square$ 


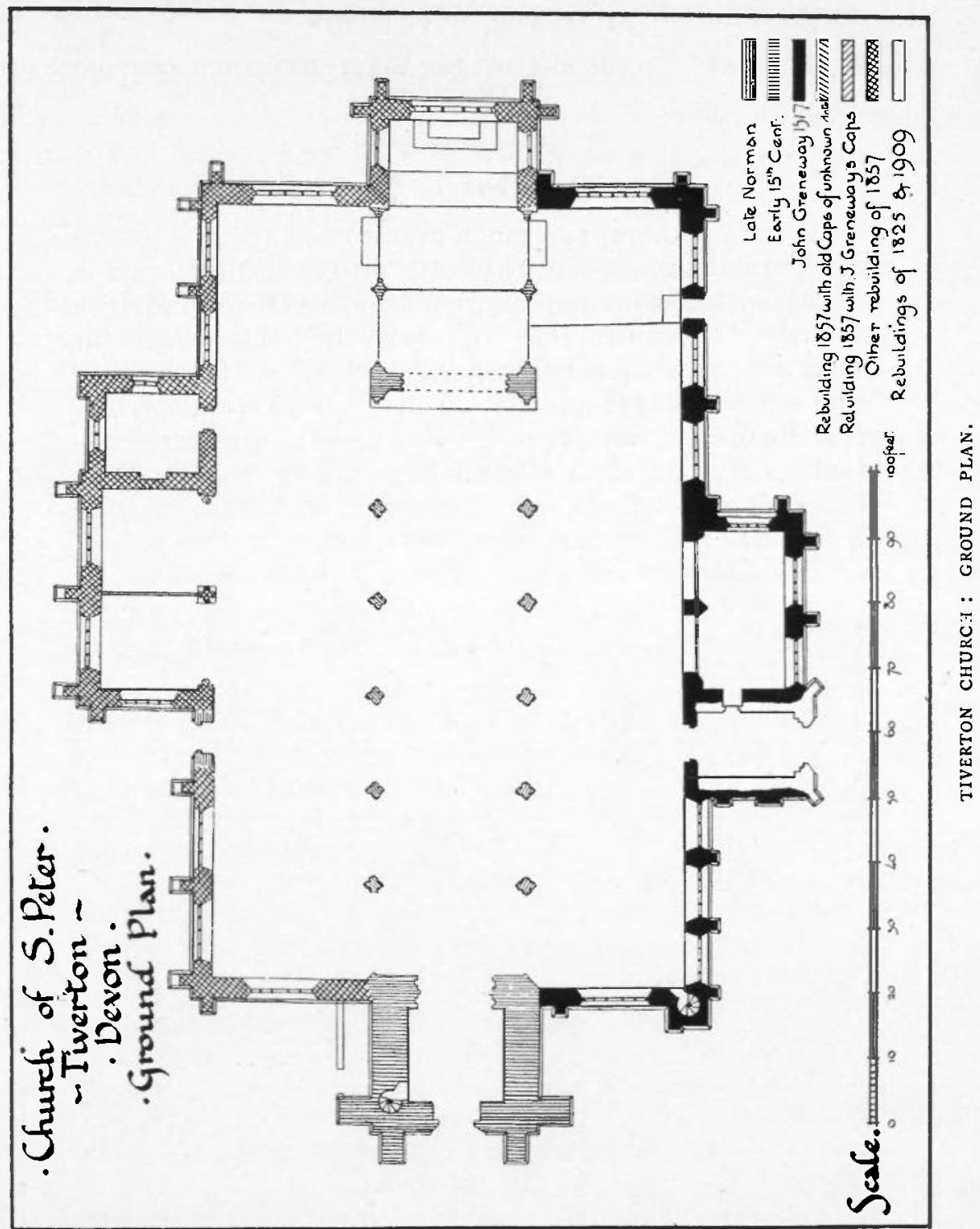


LATE MEDIEVAL SCULPTURE FROM THE CHURCH OF ST. PETER, TIVERTON.

ITS TESTIMONY TO THE ART OF THE EARLY SIXTEENTH CENTURY IN ENGLAND.

By Miss E. K. PRIDEAUX.

PART I.

We are, perhaps, too much accustomed to think of the early part of the sixteenth century mainly as the period in which Gothic art entered upon its decadence, and it is certainly undeniable that this was the time when the influence of the Renaissance, under Henry VIII, first laid hold upon the art of the country. And although the great final achievements of English Gothic architectureHenry VII's chapel in Westminster Abbey, a great part of King's college chapel, Cambridge, and the vaulting of St. George's chapel, Windsor-belong to this period, and the sturdy national 'Tudor' style of domestic architecture survived even into much later years, yet these undoubtedly marked the close of Gothic architecture in England.

In the modest field of parish-church architecture, however, there was more true Gothic spirit left than is always recognised, and, to quote Mr. Hamilton Thompson's interesting paper on Cburch Architecture in Devon, 'the despised work of the fifteenth and sixteenth centuries, as our opportunities for studying medieval history and culture are widened, is beginning to assume its true importance.' 1 And this applies, I think, as much to the decorative work on buildings as to the structures themselves, of which Mr. Thompson was primarily speaking.

In the arts of ecclesiastical sculpture and carving as a whole there doubtless had been for some time a signal fallingoff from the vigour, skill, and refinement of the earlier centuries. The noble and graceful figure-sculpture of the thirteenth century, and the superb naturalistic carving of the fourteenth century, had given place to the conventionalism which results-not from restraint in artistic work, 
but from the loss of spontaneous impulse, and the consequent constraint and imitation.

But I think that in the following illustrations of the sixteenth-century decorative work on the parish church of St. Peter, Tiverton, Devon, we cannot fail to recognise the continued existence of the combination of artistic imagination with religious feeling which had animated Gothic ecclesiastical sculpture throughout the past centuries; and they will show that, in the west of England at least, this spirit still exercised a vital influence and was far from showing signs of exhaustion.

The church of St. Peter, Tiverton (plate II, I), is not in plan of a distinctly Devonian type, inasmuch as it retains a fine chancel-arch; but the absence of a transept, and the circumstance that both north and south aisles are nearly equal in length to the nave and chancel, are features characteristic of Devon (plate I).

It has been much restored, and indeed rebuilt, in the nineteenth century, but fortunately retains enough of its early detail to afford a very important example of the standard of architectural sculpture in the west of England in the late fifteenth and early sixteenth centuries.

The work of the latter period is chiefly seen on the exterior of the south aisle, and the chapel added to it, which were built in 1517 by John Grenewaye, a wealthy woolmerchant of Tiverton, and which have marvellously survived many extensive repairs and other perilous attentions. Dunsford, the historian of Tiverton, writing in I790, says : - The front (i.e. the south face) of the church hath a noble appearance, which would have been much more venerable had not the chapel been painted and the other parts of the front plastered and whitewashed, by which much of the sculpture and some of the inscriptions are obliterated.' Since my notes and photographs were taken (in June I9I4) I regret to say that the south aisle has suffered severely from a well-intentioned enterprise for the preservation of its sculptures. On paying the church a visit in August 1917, to verify some points, I was dismayed to see the carvings of the south aisle startlingly fresh-coloured ; and on enquiry I found that they had just been cleaned and then treated with a preservative fluid. The cleaning had been effected by brushing, and that evidently of a 


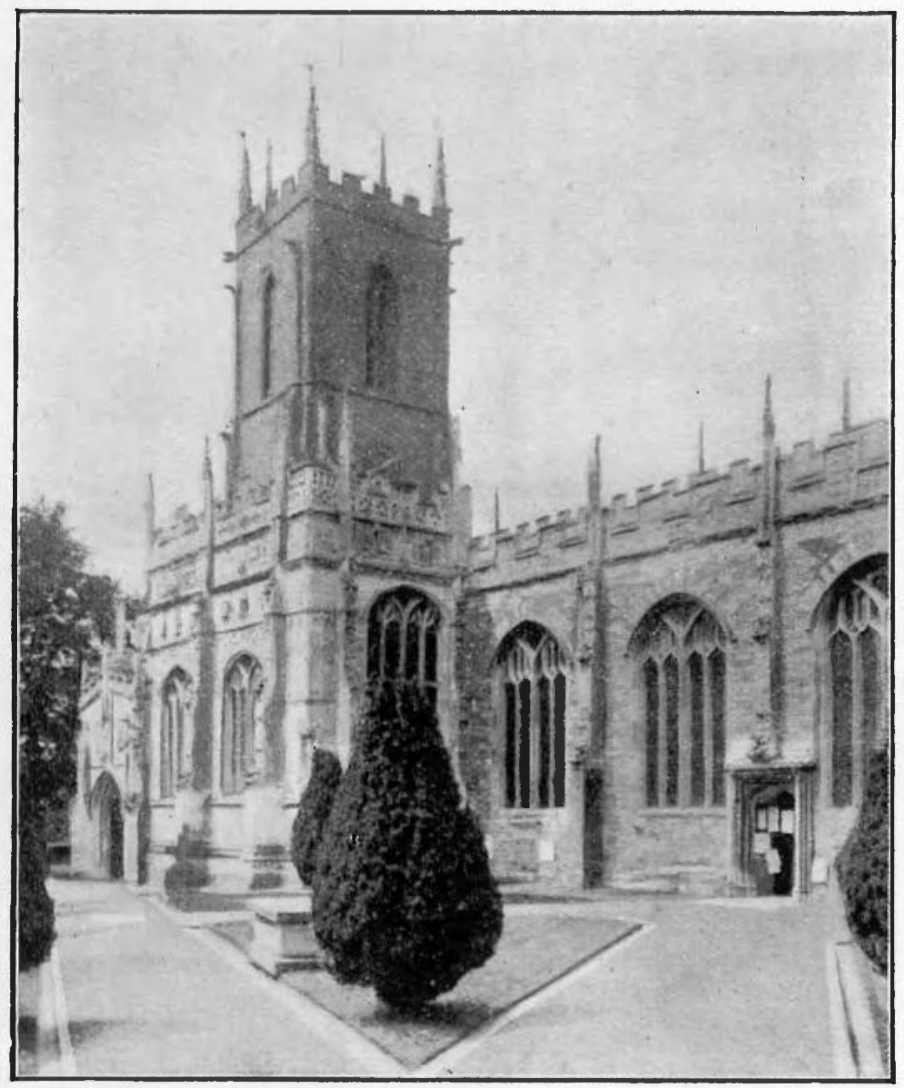

I. TIVERTON CHURCH, WITH GRENEWAYE CHAPEL, FROM S.E. 


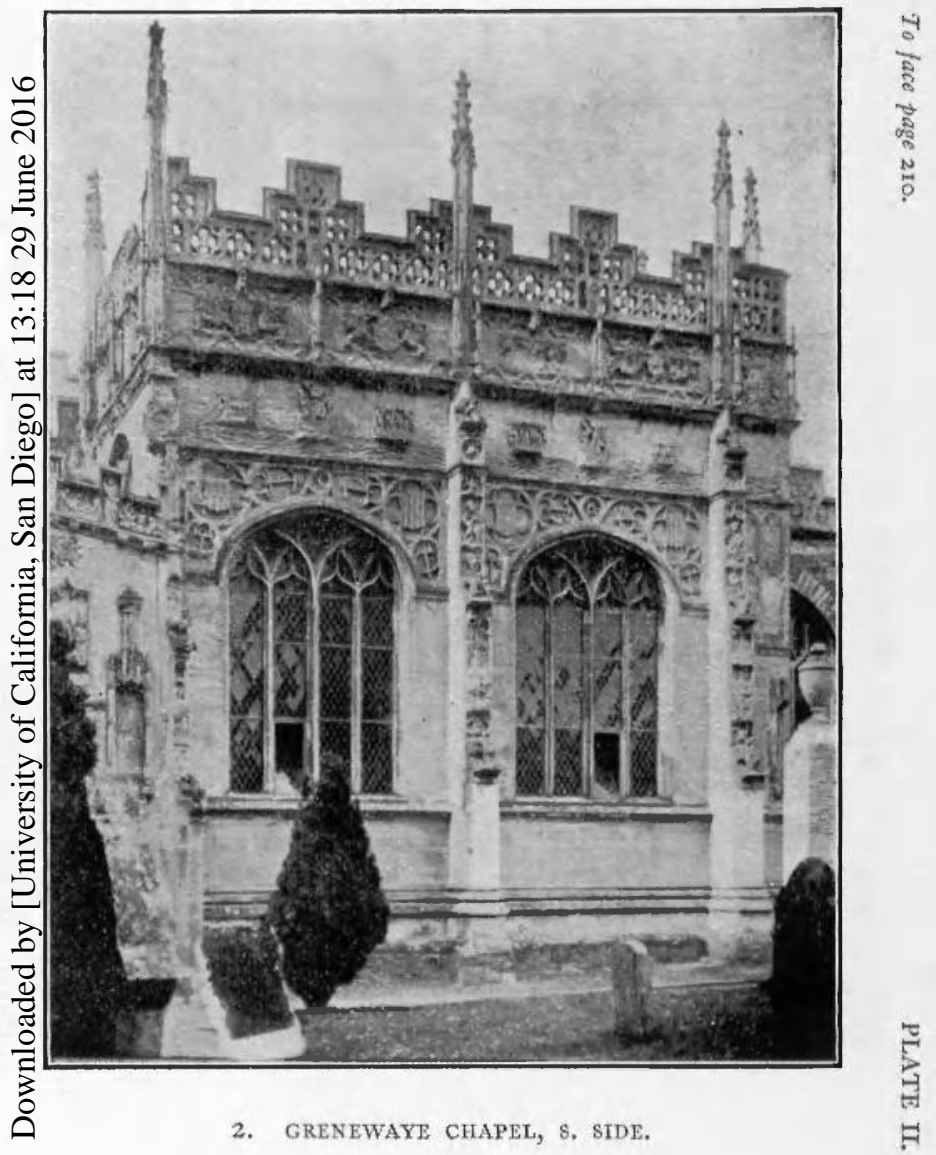


ruthlessly vigorous nature, for much of the detail-fortunately previously recorded in my photographs-has disappeared under the process, and what remains is sadly blunted. The whole result is deplorable. I heard that much of the work had been carried out by totally unskilled hands-and so it appears. Happily this destructive 'preservation' has not been extended to Grenewaye's chapel proper, though the two western buttresses of the porch are among those dealt with most harshly.

The south face of the chapel (plate II, 2) is crowded with decorative detail, of which the most complete and interesting portions are the series of twenty-one scenes from the life of our Lord, and the bold Ship frieze below it. It is the sacred series which specially testifies to the late survival of the medieval spirit in ecclesiastical art; and this will therefore be the first part illustrated. But it will add to the interest of our examination of these sculptures if I first say a few words on the historical aspect of such series of biblical scenes.

One of the most important facts concerning them is the great antiquity of the first known examples. It is on the sculptured Christian sarcophagi of the fourth and fifth centuries that the earliest representations of a series of scenes from the life of our Lord appear. On that of Junius Bassus, A.D. 359, now in the crypt of St. Peter's, Rome, occur six of such scenes, and several other sarcophagi only slightly later could be quoted. Also early Italian ivory-carvings on plaques and caskets give us many instances of representations of these scenes, dating from the fourth century onwards. Selected numbers of them also occur frequently throughout the sixth, seventh, eighth and ninth centuries in other carvings, and in mosaics, enamels and illuminated manuscripts.

In our own country the earliest known sculptures of scenes from the life of our Lord are those on the Celtic high cross at Ruthwell (Dumfriesshire) which is ascribed by a certain number of authorities to the second half of the seventh century. But it is not till about the tenth and eleventh centuries that we find the regular series of the life of Christ becoming an acknowledged feature in Christian art, and in our own country they are rarely seen before the twelfth century. An illuminated Saxon 
Psalter of the eleventh century in the British Museum (MS. Cotton, Tib. c. vi) contains, perhaps, our earliest national series.

By the thirteenth and fourteenth centuries they had become quite common throughout Christendom, and the cause of this marked increase in their production is to be traced-as Mrs. Jameson says- 'to the impassioned cry to contemplate the sufferings of Christ which arose from the founders of the two great orders of Dominicans and Franciscans, and which gave an impulse to this class of subject both in dramatic and pictorial art.' In Italy the fine series of frescoes by Duccio in the cathedral church of Siena belongs to the year I $\mathbf{Z} \mathbf{I} \mathbf{I}$, and gives twenty-six scenes of the Passion cycle; and those of Giotto in the Arena chapel at Padua are nearly contemporary with them. Gaudenzio Ferrari's complete series of frescoes of the Passion at Varallo belong to the same late period as our Tiverton sculptures.

French art of the twelfth, thirteenth and fourteenth centuries produced a specially large number of sculptures of these subjects, and in M. Emile Mâle's most interesting works on the Religious Art of France in the Middle Ages it is shown how, in the thirteenth century, the French artists in these matters followed exclusively the subjects prescribed by the Church as specially illustrative of the liturgical order of the festivals of the Church, and how, at that period, all such subjects were treated as a clotbing for dogma; while, somewhat later, the special forms adopted for these representations were undoubtedly greatly influenced by the mysteries and Passion plays of the thirteenth and fourteenth centuries, in which it was rather the realisation of the bistorical aspects of the events portrayed that was mainly aimed at. M. Mâle throws great weight upon the influence of these medieval dramatic representations of the Bible scenes, and traces the origin of the types almost uniformly used in them to The Meditations on the Life of Christ, a work usually attributed to St. Bonaventura, a Franciscan monk of the thirteenth century, but now believed to be by another monk of the same period, by name Joannes de Caulibus. It was of widespread repute in its time.

Dramatic performances of scenes from the Passion 
date back to very early times; in fact their origin is ascribed by some writers to St. Gregory Nazianzen, in the fourth century. We have the manuscript of one in our own language, The Harrowing of Hell, which is attributed by experts to a date not later than $\mathbf{1 3 5 0}$, and which, says its editor, "probably formed one of a series of performances of the same kind founded upon Scripture History.' They were very popular in England, and there is one feature in the Tiverton sculptures which may be observed as very strongly supporting M. Mâle's theory as to the direct influence of these Passion plays on the sculptures of the same subjects. This is, that all the principal figures, and most of the secondary ones, are so placed as to face the spectator, and in a great many cases where the action of the scene demands that a figure should appear in profile, still the bead is turned to the front, giving the effect of an actor on a stage looking at and speaking to an audience. There is not a single instance in our twenty-one groups of a figure whose face is turned away from the spectator, and but few in which every member of the group is not directly facing him. Unmistakably these are stage groups, transfixed into stone.

Other influences that had been brought to bear upon this particular form of art before the time of the production of the Tiverton series were the Passion cycles of the great German and Flemish engravers, Martin Schöngauer, Israel van Mechenen, Albrecht Dürer, and others. These were not always of a very ennobling type, and greatly increased the tendency to a realistic treatment of these subjects. Still less elevating were the crudely executed illustrations in the Block books of the fourteenth and fifteenth centuries, those immediate precursors and early companions of type-printing, all of which doubtless influenced the sculptor's art amongst others.

And now to turn to the closer consideration of our late, but very complete, series at Tiverton. The stringcourse on which the twenty-one groups are carved is of Beer stone, a very free stone much in favour with the local carvers of Devon. It does not, however, bear exposure well, and these groups would be even more weatherworn than they are had it not been that they gain some small protection from their position on the under side of the slope of the string-course. But as recently as 1890 they 
suffered great injury from a severe storm, and from several of the groups whole figures have now disappeared.

In Professor Prior's book, An Account of Medieval Sculpture in England, an illustration of Grenewaye's chapel front is entitled 'Tiverton, Devon; Granite sculptures of front, c. I 500'; but this is a mistake, perhaps arising from the fact that allusion had been made just before to the external carvings on Launceston church, Cornwall, which are of granite. The Launceston carvings are wonderful, considering their material, but they betray its intractable nature by their flatness; the relief is almost entirely on one plane, and, though spirited, they cannot compare as artistic productions with these Tiverton groups. A very similar series was carved on Lane's chapel, added to Cullompton parish church nine years later than Grenewaye's chapel at Tiverton, and evidently in its decorative detail strongly inspired by the earlier building. But the Cullompton series is now so defaced by exposure to weather that but few of the figures are recognisable. Beer stone was used there also for all the carved work.

Each of the Tiverton groups measures only about 9 inches in height by I I in breadth, and the work therefore is often extremely fine and delicate-almost too much so for effectiveness at such a height, for this string-course cannot be much under 30 feet from the ground.

The series begins on the western side of the chapel, on which five groups are carved. These are all scenes from the life of our Lord before the commencement of the Passion cycle, and, unlike most representations of this portion of His life, the series omits the earliest scenes of all, and begins with (I) The Flight into Egypt (plate III, I). Examples of the appearance of this subject can be quoted from the fifth, sixth and seventh centuries, but it was not common in those early days. On the high cross at Ruthwell, already mentioned, is its earliest appearance in Britain, and it appears on some of our twelfth-century Norman fonts. The usual number of figures introduced was, as here, three, and their grouping also was much the same as in our specimen; and there was but little variety in the general treatment throughout the centuries. We may note that Joseph is here distinctly represented as an old man, with sunken mouth and cheeks. The figure of the Holy Child 

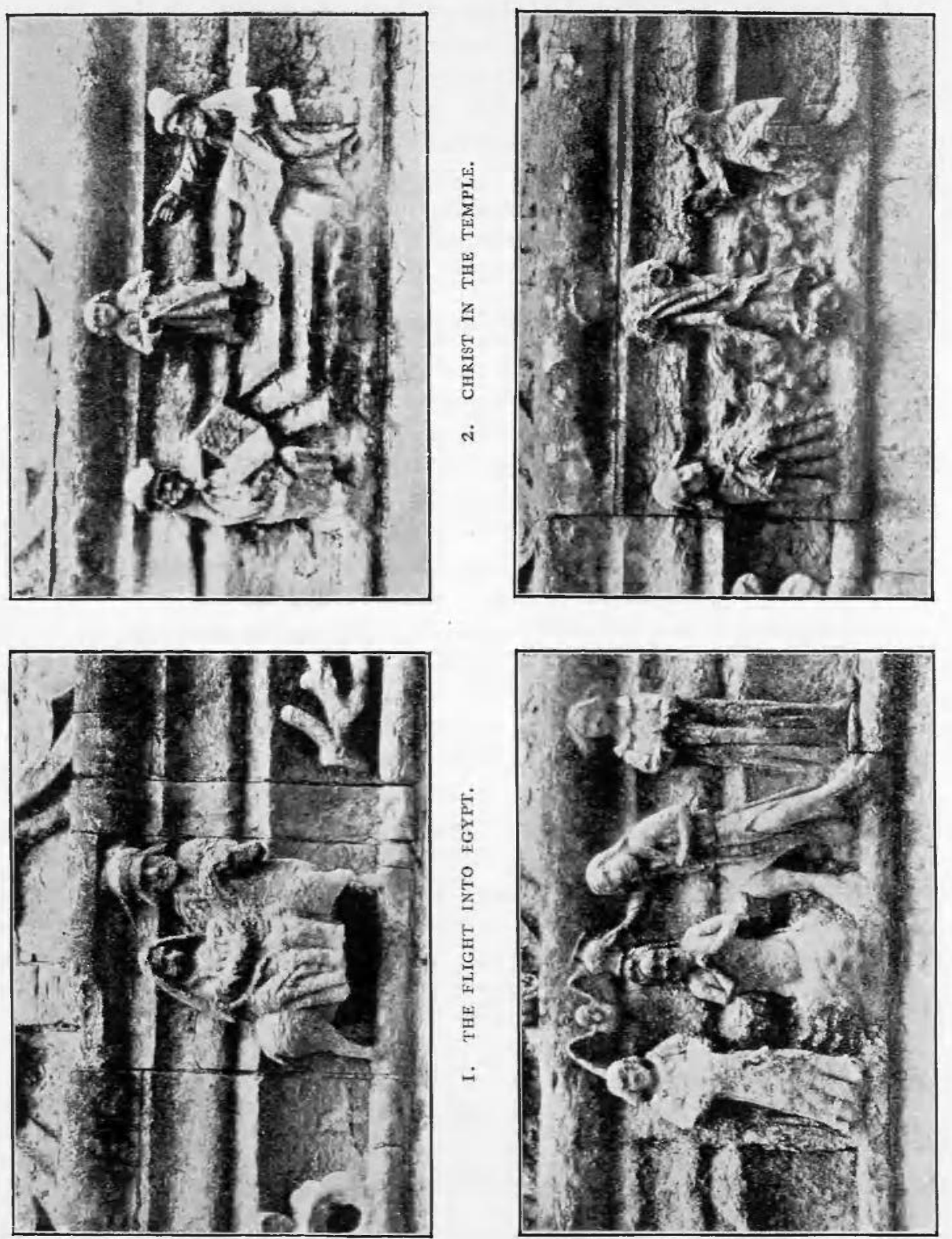

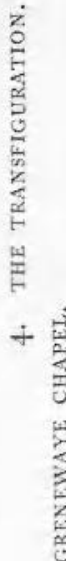

范

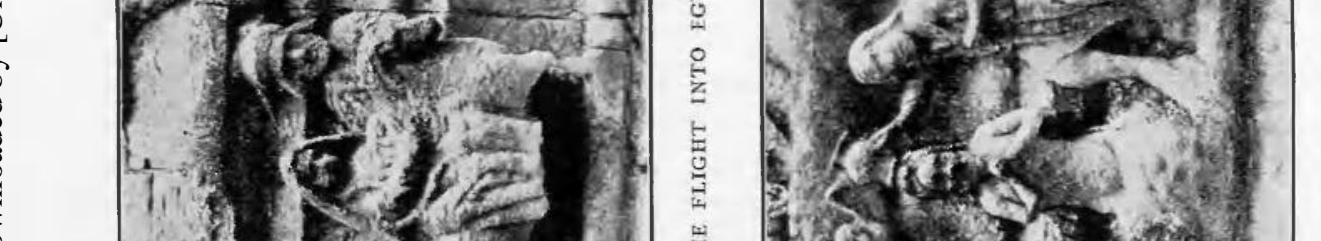

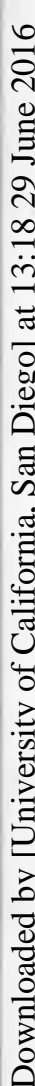


and much detail of this group have almost disappeared; but in the next scene, that of (2) Cbrist disputing with the Doctors in the Temple (plate III, 2), there is no lack of interesting detail. Like the last subject it is found early in art, in the fifth century, but it is not a very common subject at any period. An English example of the thirteenth century appears among the bas-reliefs of the tympanum of the west doorway of Higham Ferrers church, Northamptonshire. In some cases many more doctors are seen than the two typical ones given here; indeed in a fourteenthcentury English manuscript in the British Museum there are fourteen confronting the youthful Christ. But at any rate there is nothing lacking here in expression, both as to faces and attitudes. The outstretched finger of the Rabbi on the right, and of our Lord, always indicated in medieval art the act of teaching or preaching. This subject usually closes the cycle of scenes from the Infancy of our Lord ; and the next one, (3) The Baptism (plate III, 3), is the first of the cycle of His Ministry or public life. It is one of the most favourite subjects in early Christian and medieval ecclesiastic art, and is found continuously from the fourth century onwards, not only as one of a series but also independently. Its earliest appearance in these islands is among the sculptures on the cross of Kells, of the ninth century ; and, as might be expected, it was often chosen for the decoration of fonts-that at Bridekirk, Cumberland, of the twelfth century, being a particularly good early specimen. The type employed varied very little from first to last, so that our Tiverton example is quite representative of all periods in the main design of the group, and requires no explanation except perhaps to note that the figure on the extreme left hand is an angel holding our Lord's garments, and the one on the other side is merely a bystander in an attitude of adoration. The Dove is duly prominent, hovering near our Lord's head, and is somewhat out of scale.

(4) The next scene is $T$ be $T$ ransfiguration (plate III, 4), and this, although it dates back to Ravenna church-mosaics of the sixth and eighth centuries, was not one of the scenes unfailingly represented in series of this kind. In the early Ravenna example only a head of Christ is shown, in the centre of a jewelled cross, with demi-figures of Moses and 
Elias on either side, and the three disciples are merely symbolised by three sheep; but a more realistic treatment soon became general, and with some early exceptions the accepted arrangement of the figures was as given here, although the three disciples on the ground are scarcely discernible in our specimen, owing to their foreshortened positions and to much decay. St. Peter lies to the right, his head slightly raised, and St. James and St. John are prostrate on the other side. The little mound representing the 'high mountain,' and the curling lines beneath our Lord's feet by which the clouds are represented, are the conventional methods in medieval art of indicating these details.

(5) The last one of the western groups, and of the antePassion subjects, is the scene of Mary Magdalen anointing the feet of Christ (plate Iv, 5), which has suffered so severely from decay that its details are somewhat doubtful. However, we see the Magdalen kneeling beneath the supper-table, and can distinguish the mass of long loose hair by which, in art, she is usually identified. The figure on the left conforms most nearly to the type given to our Lord in this series, and the one at the other end would be that of Simon, the host; but this identification is open to question. The distinguishing nimbus of earlier days was no longer in use at this period, which is attributed by $M$. Male to its having been too awkward a detail for wearing in the acting of the Passion plays. The gesticulating figure at the back is undoubtedly Judas, indignantly expostulating against the Magdalen's act. On the table beside him lies what looks like the 'bag,' or wallet, of which he was in charge. This subject is not commonly found among those selected for illustrating the cycle of the ministry of our Lord in either early or late periods of art ; but it does appear on the high cross at Ruthwell, and in the Biblia Pauperum, and the Speculum Humanae Salvationis of the fourteenth century, it takes its place, as here, immediately after the Transfiguration.

(6) The next scene, which is the first on the south face, is also the first of the Passion series proper, and the subject, as was usual for the first scene, is that of Christ's Entry into Ferusalem (plate Iv, 6). It is one of the subjects dating from the fourth century, and the earliest example of it 

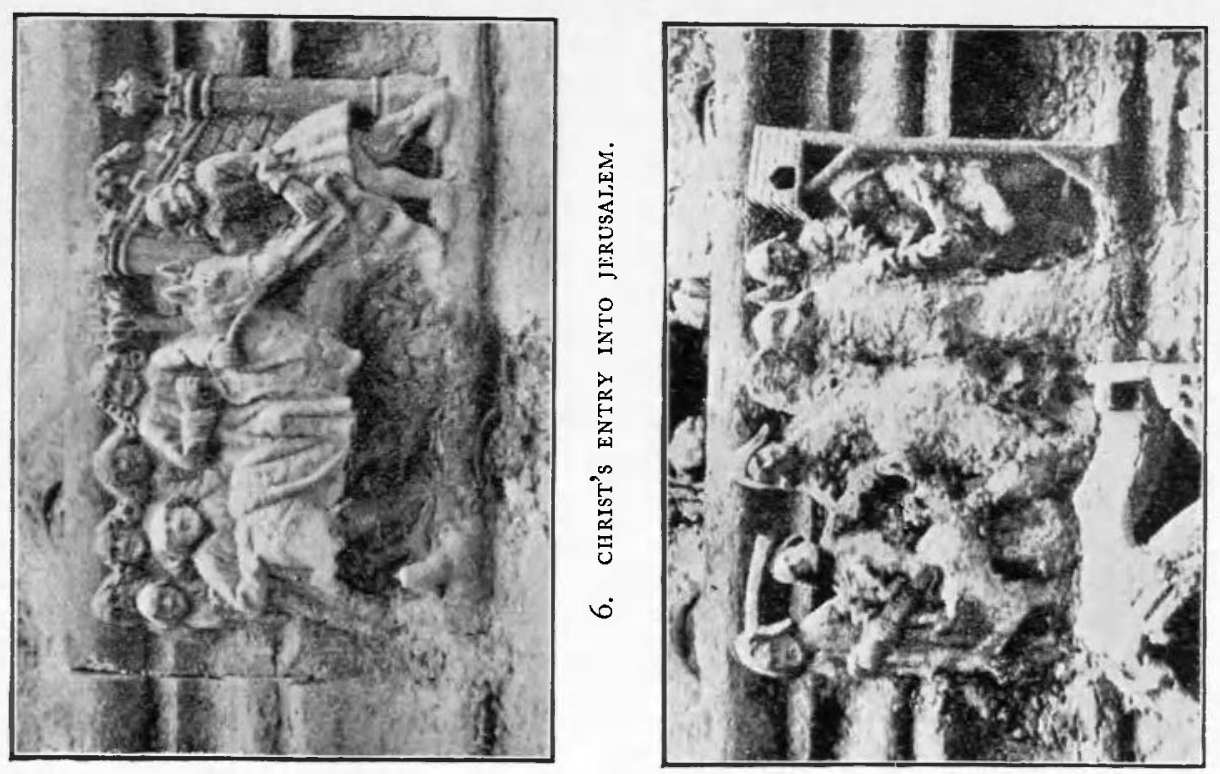

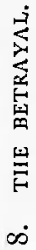
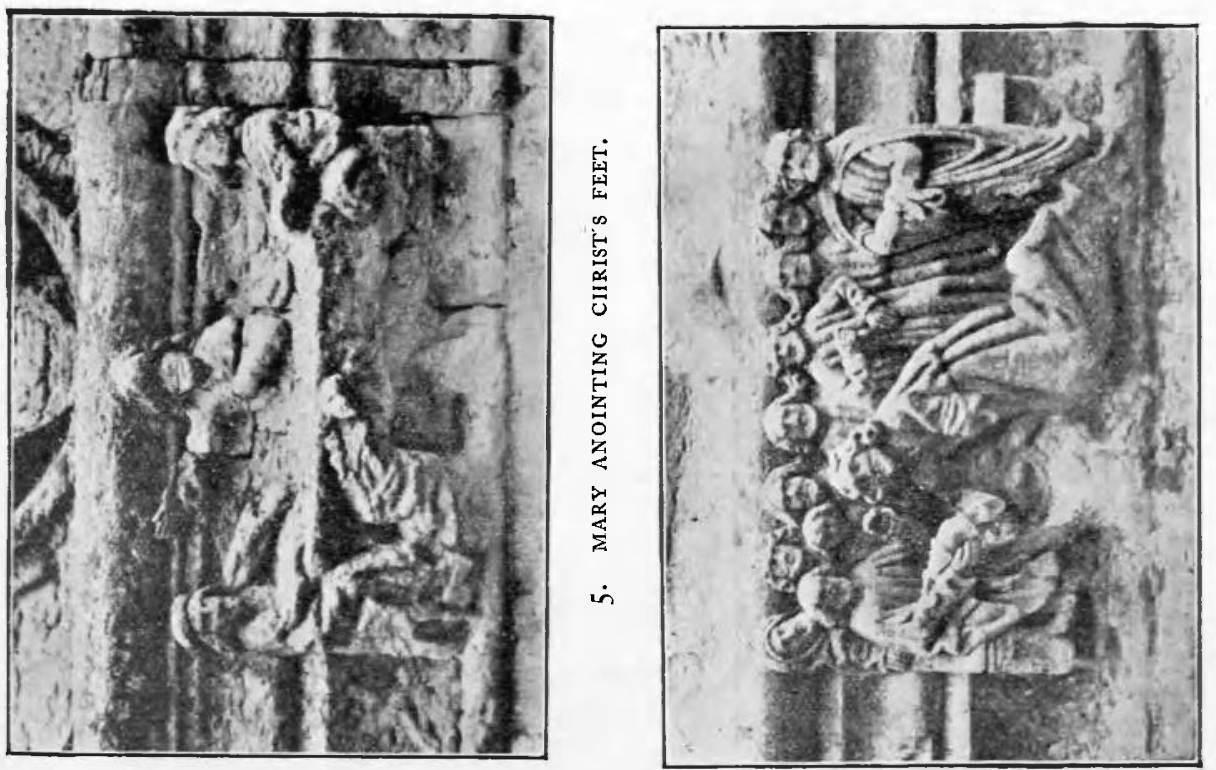

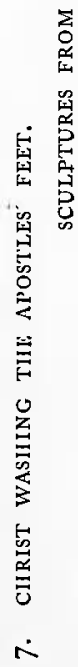



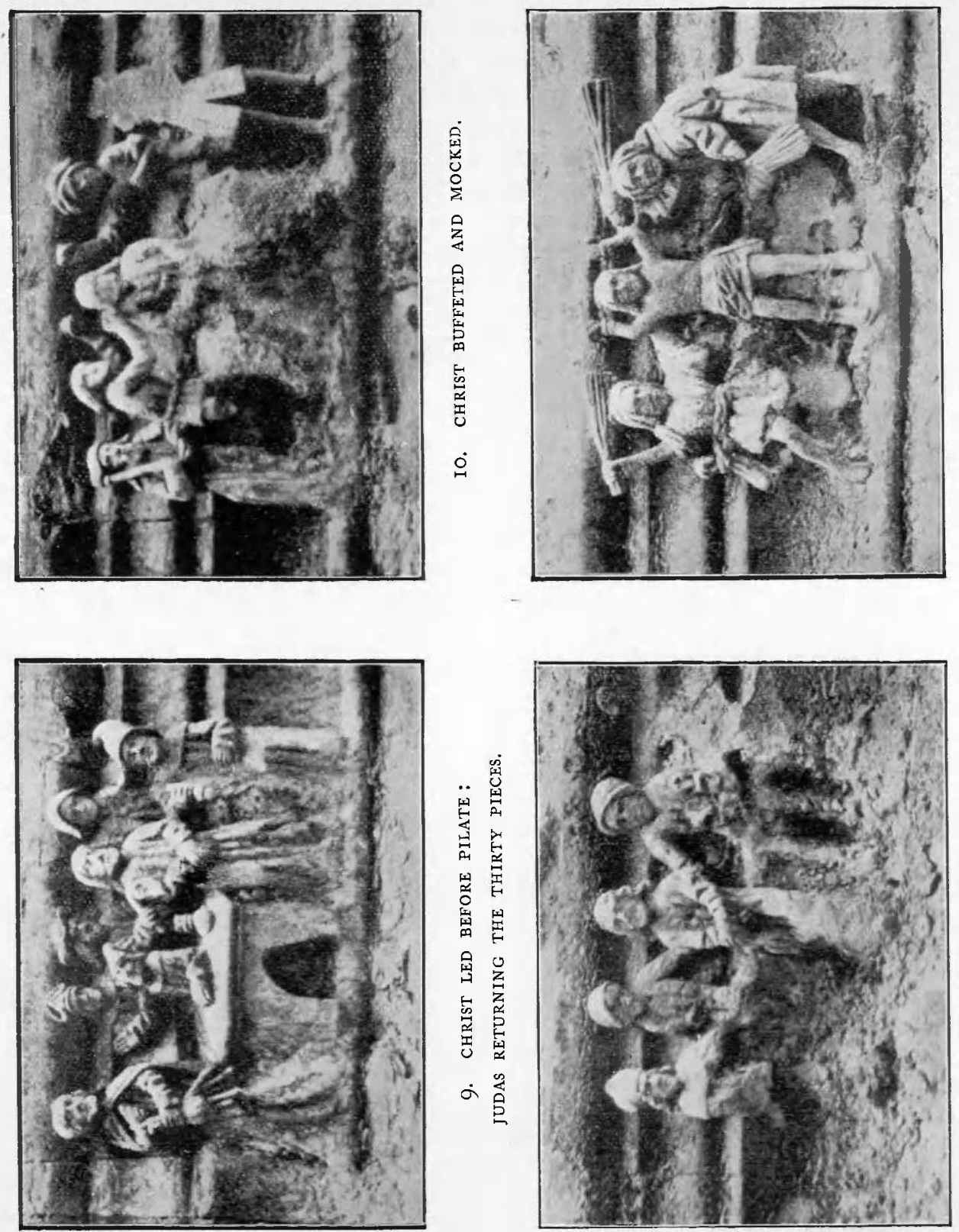
in our own country is in the seventh-century Saxon Gospels, now at Corpus Christi college, Cambridge. Its main characteristics altered but little with time, the element of a triumph being always essential to it. We see the gates of Jerusalem on the right with one citizen's head showing over the battlements, and outside them the conventional palm-tree which, in medieval art, always formed part of the scene. One man, representative of the "very great multitude,' spreads his garment in the way, and the garments cast upon the ass by the disciples are also prominently visible.

(7) Next follows the scene of Cbrist wasbing the Apostles' feet (plate Iv, 7), which is one rarely omitted from the Passion series at any time, and is found among the sculptures on the fifth and sixth-century sarcophagi. A remarkable early slab, probably Saxon, built into the wall of Wirksworth church, Derbyshire, exhibits the earliest sculpture of this subject known in England. In all cases, as here, the moment of action chosen is that when Christ is washing, or about to wash, Peter's feet, and that apostle is usually represented raising one hand, or both, in remonstrance; here we see his left hand thus raised. On the extreme right is Judas, represented, according to traditional use, as about to leave the company. The details of his head, face, and clothing should be carefully noted, as we shall recognise them in another group presently, and they differ slightly from those of the other apostles. Judas is seldom given any positive indications of villainy in his appearance by medieval artists, though a somewhat lowering expression is often seen on his face. In the Byzantine Guide to Painting he is given a dark nimbus in this scene. The position of our Lord's head in this group should be observed. It is turned towards the spectator rather than to St. Peter, thus illustrating the influence of the stagelike grouping mentioned before.

(8) The Betrayal in the Garden (plate Iv, 8) is the next subject; but unfortunately the details are very indistinct, as this group has suffered more than any but one other from drippings, being beneath the projecting base of a pinnaclet above. In reality there are two subjects combined here, an instance of the common medieval custom of compressing two or more successive moments of action into one scene. On 
the right centre is our Lord receiving the kiss of the traitor (both figures have lost all detail) while two soldiers seize Him from behind. The little pent-house conventionally stands for the garden gateway according to the late medieval method of indicating that the scene is in a garden. On the left, our Lord again, His arm grasped by a soldier, is in the act of healing the ear of Malchus who is falling smitten to the ground, while another soldier, on the extreme left, is sheathing (or drawing ?) his sword. The figure of Malchus has entirely scaled off, and it is only by its scar on the stone that we can discern its falling posture. This episode of the smiting and healing of Malchus is one never omitted in medieval representations of the Betrayal. It was very usual for the guard-attendants of Judas in this scene to be represented in gross caricature, and in an English Psalter of the late twelfth century they are shown as black men. Very good examples of this custom of caricaturing all the attendant persons taking an active part in the mal-treatment of our Lord are found in the groups sculptured on the interior of the large fourteenthcentury east window of Dorchester abbey church, Oxfordshire, where in the scenes of the Betrayal, the Scourging, and the Bearing the Cross, all such persons are made grotesquely hideous. The Betrayal scene in this Dorchester series corresponds closely with our Tiverton one in its conception, there being given in it, in a very small space, the traitor's kiss and the cutting off and healing of Malchus' ear simultaneously.

The whole scene was, throughout all periods, a constant subject in the Passion series, while detached parts of it, as the seizure of Christ by the soldiers, or the traitor's kiss, are also found in the very early centuries. Among the sixth-century mosaics at Ravenna the traitor's kiss appears.

(9) The next group is again a two-part scene, but not of successive moments; it shows two simultaneous incidents which occurred apart from one another in reality, but are here presented in one group. ${ }^{1}$ The four figures on the right belong to the scene of Christ being led into Pilate's presence for the first time (plate $\mathrm{v}, 9$ ). On the extreme right, Pilate-wearing a high head-dress unlike that 
of any other person-is seated on a kind of throne, and grasps in his right hand the hilt of a sword, of which the rest is broken away. Our Lord stands before him bound and held from behind by a rope of which a scribe has the end ${ }^{\mathbf{1}}$; and a common soldier also stands behind, wearing, as in the last scene, a medieval sallet or small helmet, and carrying a medieval halberd. The scene on the left is composed of three figures, viz. Judas on the left front carrying 'the bag' and identical in feature and clothing with his figure in the scene of the washing of the apostles' feet. On the table from which he has just turned is the large bag of money which he has thrown there ; and the figure leaning across the table is evidently in the act of saying to him, with a gesture of angry repudiation : 'What is that to us ? See thou to that!' In the background stands one of the chief priests, distinguished by his mitre-shaped head-dress.

This subject of $\mathcal{F}$ udas returning the money is very rarely found in any Passion series; but the other, of the appearance of Christ before Pilate, is quite common from the fifth century onwards.

(I0) The next scene (plate $v$, IO) seems to represent the Buffeting and the Mocking in one, for the figure on the extreme left is apparently our Lord, carrying a sceptre and wearing a crown (unless this is intended for Herod), while the central one is undoubtedly also our Lord, seated among His tormentors. The figure on the extreme right has been scaled off for many years. This subject is not found on any of the most ancient monuments, but was included in many Passion series earlier than this one, and is usually much dwelt upon in contemporary works of art.

(II) Next follows a second representation of Christ before Pilate (plate v, II), evidently at the time when, standing bound between $\mathrm{His}$ accusers and $\mathrm{His}$ judge, ' $\mathrm{He}$ answered him to never a word.' The figure of Pilate, on the extreme right, has entirely broken away, except the point of his distinctive head-dress, which can be seen still attached to the top of the string-course, and the hilt of the sword which he held in his right hand; but in some photographs of these groups taken in 1905 , and reproduced in a book 
on St. Peter's church, Tiverton, by the Rev. Edwin Chalk, this figure is still intact, and gives the clue to the whole scene. Pilate is seated, as before, on a kind of throne, and bends eagerly forward in a listening attitude, while at the other end is an accusing chief priest, wearing (as was noted in a previous scene) a mitre-shaped head-dress, and with a face most expressive of malevolence and cruelty. This scene was usually included in the Passion series of this late period, though not very frequent in those of earliest times.

(12) The Scourging of our Lord (plate v, I2) is the next subject, and requires no explanations; but we may note the restraint and reverence with which the subject is treated by the Tiverton artist in contrast to the tendency shown in many contemporaneous works of art, notably those of the German engravers of the sixteenth century, in which the introduction of a low and degraded type was common. It is very noticeable how the scourgers in this group face round to the spectator rather than direct their looks towards their victim-another instance of the stage influence already pointed out. This subject does not appear farther back than the eleventh century, but from that time became increasingly popular till, by the fourteenth century, it was scarcely ever omitted from the Passion series in all forms of art.

(13) The next, the Crowning with thorns (plate vi, I3), is also a subject scarcely met with in early art, and only commonly adopted in the fourteenth century. In this specimen we see a detail characteristic of all contemporary representations, viz. the long, pronged forks with which the men on either side are placing the crown in position, used as a means of avoiding the actual handling of the instrument of torture. Our Lord's figure here has suffered more than usual decay from the same cause as in the Betrayal scene, the concentrated drippings from an overhead projection.

(I4) The next scene, Pilate wasbing bis bands (plate Iv, I4), is another good example of the compression into one group of a sequence of actions. It shows Pilate, still distinguished by his peculiar head-dress, seated, and in the act of washing his hands in a basin held by a small, kneeling servant, whose head is much damaged. On the right stands 
a chief priest, in medieval priestlike dress, and with shaven face, as before, gesticulating and evidently demanding the crucifixion of Christ, who stands, bound, on the other side of Pilate. In the rear, between Pilate and our Lord, is Pilate's wife, looking towards him with her hands folded in an attitude of entreaty. The other figure, on the left, seems to be one of the multitude following the example of the chief priest. This subject appears both early and late in works of art of various kinds, but is not uniformly included in all Passion series. Amongst us it is first found in the tenth century sculptured on the cross of Muiredach at Monasterboice (co. Louth). The episode of the dream of Pilate's wife is not very often given, but it occurs on a boss in the fifteenth-century nave-vault of Norwich cathedral church.

(15) The group following this is that of Christ bearing His Cross (plate vI, I5), a subject which is one of the most constant in all Passion series of every period from the fifth century downwards. It was treated very reverently in the earlier periods, but in works of art contemporary with this sculpture there is frequently shown a distasteful tendency to dwell realistically on the most painful incidents of the scene (or scenes, for the subject was often drawn out into several successive stages). It is therefore a matter for appreciation that we again find the Tiverton artist confining himself to a severely simple representation of the mere essentials of the scene, and not introducing either the legendary or exaggerated elements with which the subject had become crowded in the works of the artists of his day. Here Simon of Cyrene, behind, is in the act of relieving Christ's shoulders of some of the weight of the Cross, which he prises up with his outstretched foot; and the soldier in front is shown as haling Simon to the task from amongst the crowd. To touch the instrument of shame was abhorrent to a Roman citizen, and therefore a man from the countryside ('a stranger and foreigner' he is called by Lady Eastlake in her comments on this episode) was summoned to assist. The bearing his own cross was a part of the sentence reserved for only the worst and most degraded malefactor.

(I6) In the next scene, that of the Crucifixion (plate vI, I6), which is the last on the south face, we meet with some disappointment, regarding it as a work of art, for the central 
figure is badly proportioned and altogether very inferior to most of those we have already seen. And, judging from the conspicuous V-shaped jointing of the stone, it seems probable that this portion of the group was, during some repairs, obliged to be replaced by new work, - not new work now, but of a later date and by a less skilful hand than the rest of the carving.

The scene as a whole conforms to the type common to the period after it had gone through many varieties from the fifth century onwards. The frequency of its appearance through all the Christian ages affords material for quite a history of its development and treatment, which is too large a subject to be even touched upon here; but those interested in it can read much of this in Mr. J. Romilly Allen's Early Cbristian Symbolism, and in both M. Emile Mále's volumes on Religious Art in France in the Middle Ages - all most illuminating works. The earliest known sculpture of the Crucifixion, in Britain, is that on the high cross of Ruthwell ; and it is found frequently on Irish crosses of the ninth and tenth centuries. In this late group we have, besides the central figure, the Virgin and St. John kneeling together on our left; in earlier times these two were always placed on either side of the cross, but this alteration of the grouping is characteristic of a late date. The two other Marys stand behind them, and a soldier with a spear still further at the back. On the right are the remains of a group of three soldiers disputing over the raiment of our Lord, which the one in front holds in a bundle in his arms. This incident was introduced into the scene, in art, from very early times (it is known in the sixth century) and continued common to it up to the late date of the Tiverton work.

This group fills the last block of the string-course before it turns the south-east angle of the chapel, and the remaining five occupy the portion running along its eastern face. The first of these is (I7) the Descent from the Cross (plate viI, I 7), which originally showed all the usual figures essential to the subject, viz. Joseph of Arimathea kneeling on the left to receive the dead body, and grasping the stiffened legs with his right hand (the arm and his face have crumbled away within the last few years). Then the Virgin, just behind him, supports the head of her Son on her shoulder; 

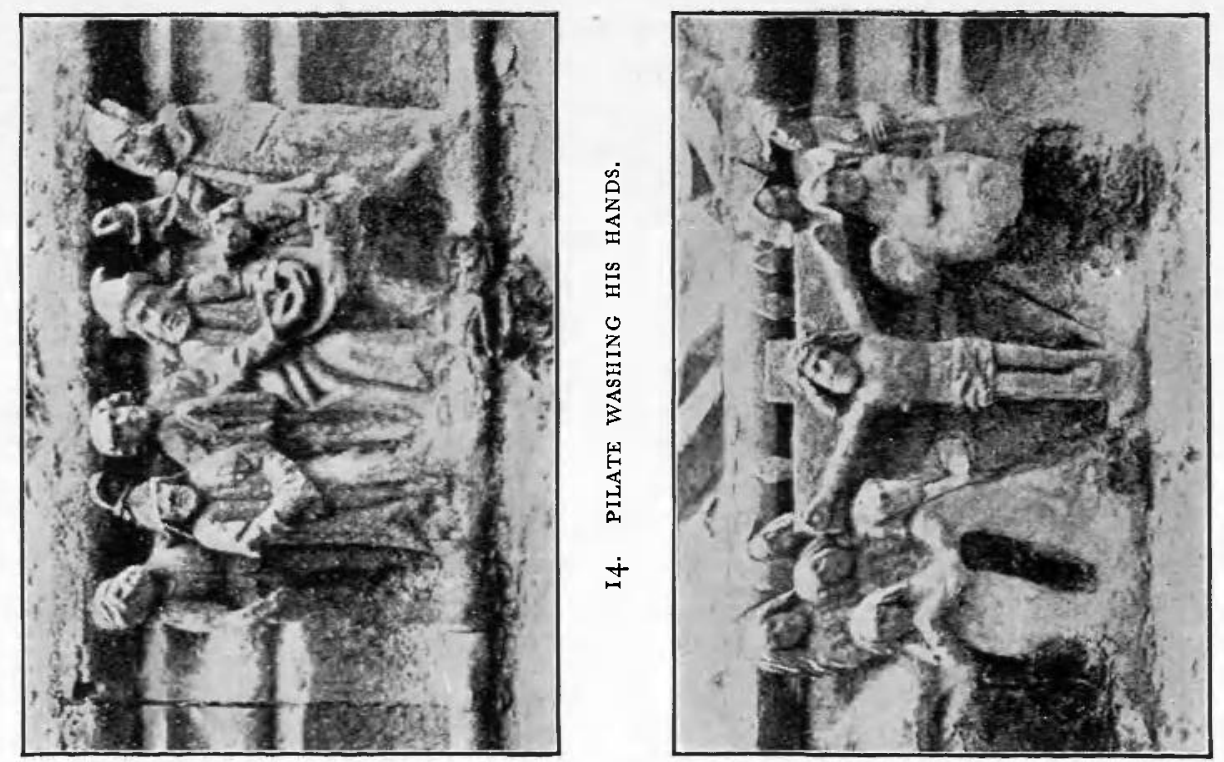

空
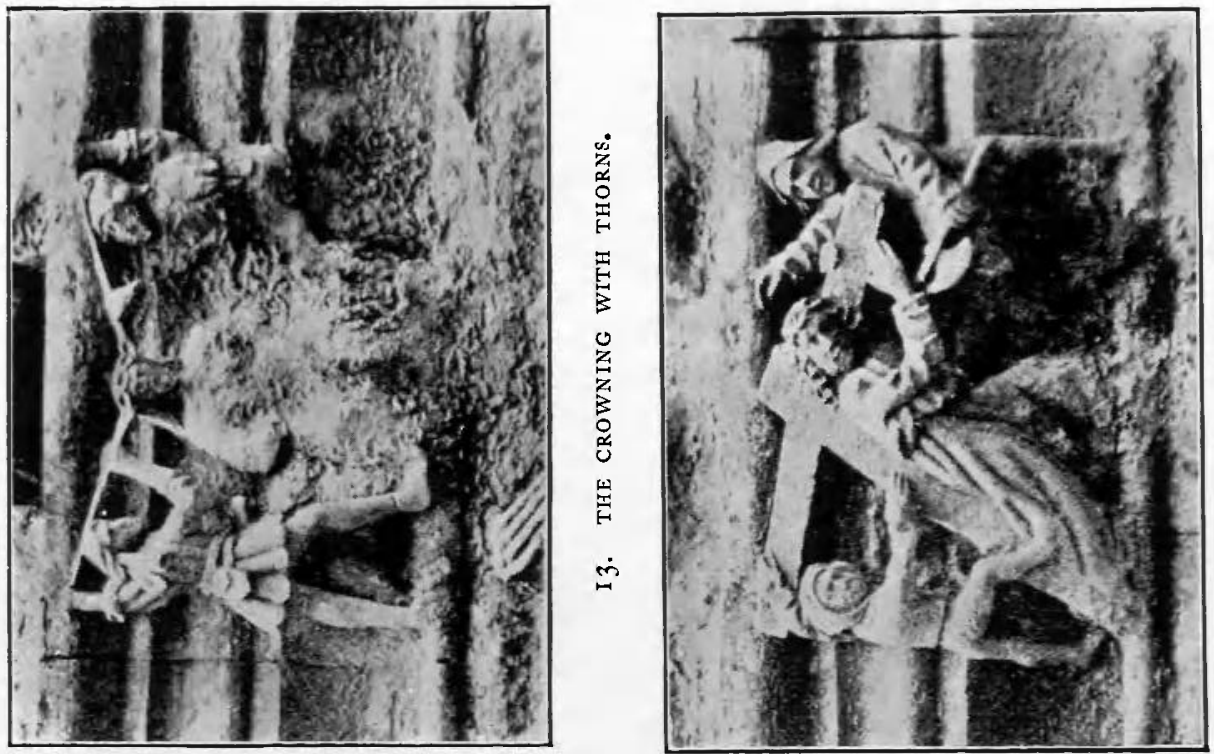

踏

范

告

넙

垈

占

in 

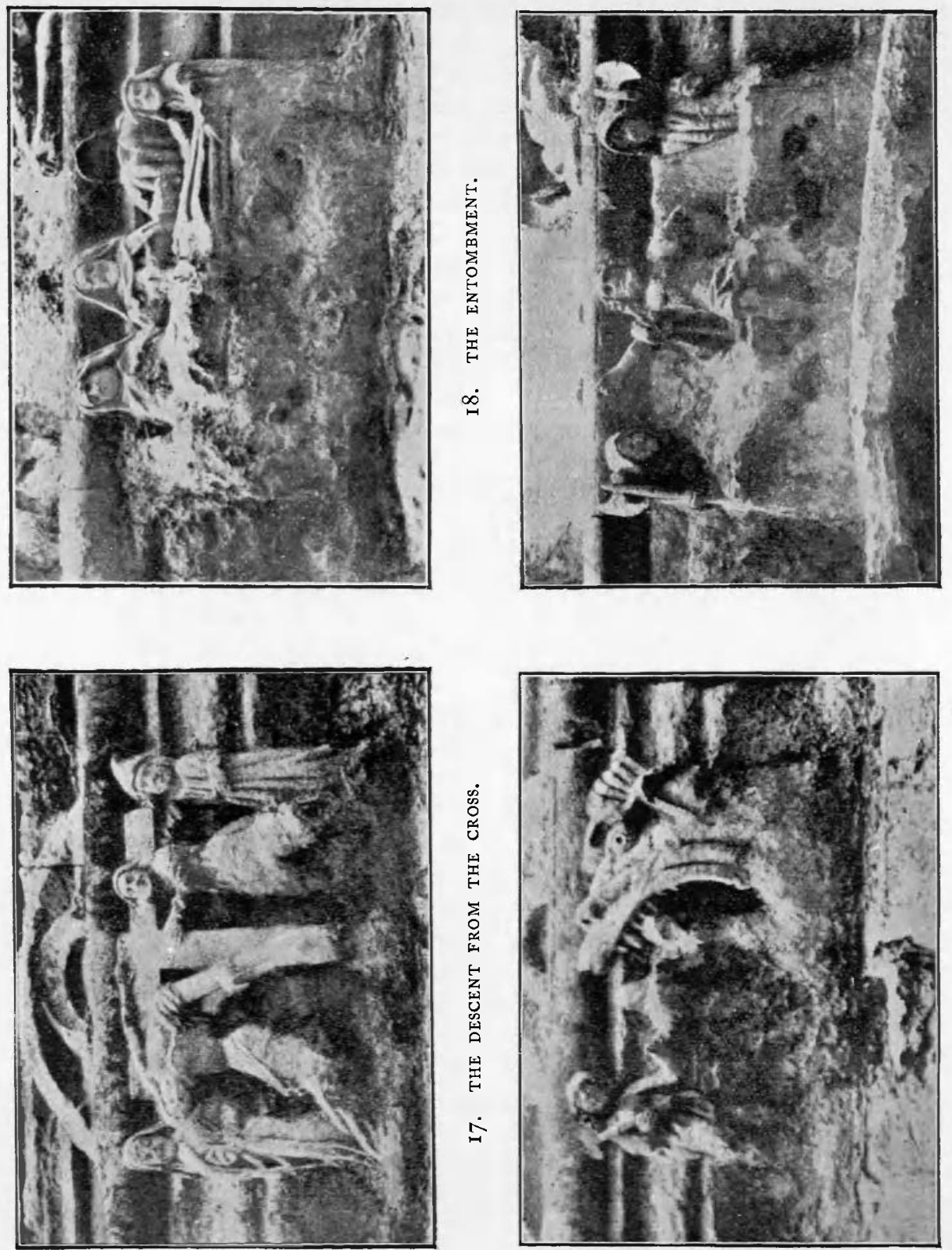

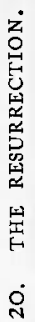

. 
St. John leans against the cross on the right, and has apparently just released his hold of the sacred body; and Nicodemus stands by his side. Below Nicodemus was once another figure, doubtless that of Mary Magdalen, kneeling at the foot of the cross, the position in which she is customarily placed in this scene; but nothing more of this figure now remains than the scar on the stone behind and a little drapery on the ground.

Though not found in very early Christian art, this subject was subsequently a favourite throughout all periods. The earliest known English sculptures of it belong to the twelf th century (on a capital in Adel church and on a font at North Grimston, both in Yorkshire.) A much mutilated contemporary carving of it occurs on the screen of the Sylke chantry chapel in the north transept of Exeter cathedral church.

This group from the Tiverton series seems specially closely related to the tableaux vivants of the early Passion plays, in the very pronounced outlook of its figures towards the spectator. None of them seem to be really giving any attention to the figure on the cross, but all stand, posed in appropriate attitudes, turning their faces to the front. Very different is the impression given by many earlier examples, where the attention and emotion of every other figure in the scene is concentrated on the central dead figure.

(18) The next group, the Entombment (plate viI, I 8), has suffered great loss from decay. The head of our Lord's body, and the figure of Nicodemus standing at the head of the tomb, have both entirely disappeared. Joseph of Arimathea is the one holding the shroud at the foot of the tomb; and the three behind are the Virgin, nearest the head, Mary Magdalen in the middle, and St. John last. ${ }^{1}$ This subject is not known to have appeared in art before the eleventh century; and it was not until the fourteenth century that it became established as a member of the Passion series, while it is to the fifteenth and sixteenth centuries that belong those large sculptured groups of the scene so often placed in recesses in French churches and called 'Holy

1 This photograph, and the last, suffer a good deal from excessive tilting of the camera, which foreshortens the figures, and also gives to some of them the appearance of having their heads thrown unduly backwards. 
Sepulchres '—often very beautiful works of art. In them the arrangement of the group is almost precisely the same as we have here.

(19) The following scene, known in medieval times as $T$ he Harrowing (or Despoiling) of Hell (plate vir, 19), represents our Lord visiting the spirits in prison (or Hades), and releasing thence Adam, representative of all mankind, whom He takes . by the hand; and Adam leads with him Eve also, to render the representation complete. In many examples numbers of other souls press out behind Adam and Eve. The figures here have become sadly imperfect, but our Lord with the small cross of the Resurrection (or triumph over death) on $\mathrm{His}$ shoulder, and $\mathrm{His}$ hand grasping that of Adam, can be clearly seen. Also the monster's head which symbolises the jaws of hell is very clear, and thoroughly conforms to the conventional type adopted for this feature of the scene. Its origin lies in the description of Leviathan given in the $4^{\text {Ist }}$ chapter of Job, in which early commentators (including Gregory the Great) recognised the image of Satan and his works. Many of the details shown here, such as the teeth, etc. (see verse I4), correspond very literally with the scriptural description.

There would not be time now to enter into the interesting origins of this most popular scene, beyond noting that the belief on which it is grounded was firmly held as far back as the second century; and that, far beyond this scripturally-founded belief, the scene derived its development and details from the Apocryphal Gospel of Nicodemus, a Greek manuscript of uncertain date, though attributed by some to the second century, in which every circumstance of Christ's visit to Hades, or Limbo, is dramatically described. Hence the subject became an unfailing favourite in Passion series from the eleventh century downwards; and it forms the theme of the earliest surviving mystery play in our own language, which belongs to the first half of the fourteenth century. In sculpture we see it on one of the eleventh-century slabs inserted in the west front of Lincoln cathedral church.

(20) The Resurrection (plate vil, 20), which follows as the next scene, is represented with much simplicity and dignity, and is not wanting in artistic power. Our Lord steps forth from the opened tomb, the lid of which is seen raised and 
pushed on one side; and His right arm and hand are uplifted in the act of benediction, while His face (better seen from some other aspects than in the photograph) wears a striking expression of triumph. The two Roman soldiers of the guard who stand on either side in the rear, each holding a medieval halberd, show by the droop of their heads that they are overcome with slumber.

This subject was not usually represented in art till

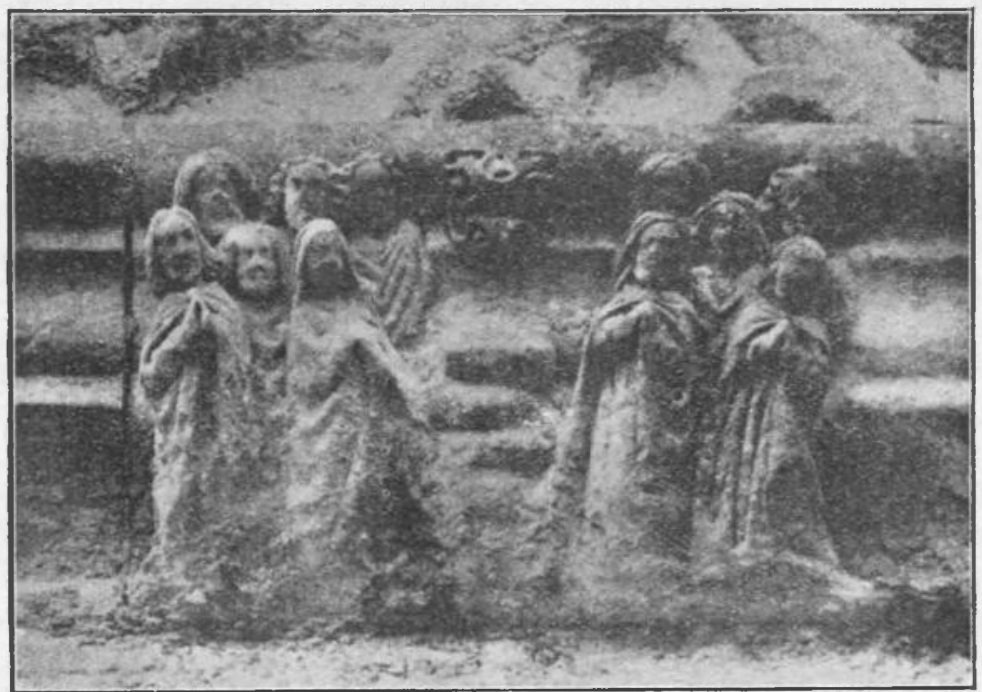

Fig. I. SCULPTURES FROM GRENEWAYE CHAPEL: THE ASCENSION.

much later than most of the others of the series, doubtless because no description of the actual event is found in the Scriptures. It was implied by the two other scenes-of Christ's descent into Hades, and the visit of the women to the empty tomb. It appeared, however, in the thirteenth century under the influence of "the revival of religious fervour in that notable period,' when 'for purposes of conviction' (says Mrs. Jameson in her History of our Lord in $A r t$ ) it was included among the tableaux vivants of the Church on Easter day.

(2I) The last scene, that of the Ascension (fig. I), appears quite early in art, in the sixth century, and in English 
work is found in Anglo-Saxon manuscripts; and it was very freely represented throughout Christendom in all subsequent periods and in all forms of art. Its treatment from time to time, and its distinctive characteristics, can be allotted to certain periods, but it is unnecessary to enter into these now. By the time of the production of our Tiverton group, almost all symbolism, so rife in the earlier periods, had vanished from it, and it is a fair though very uninspired specimen of the contemporary type. The only noteworthy feature to remark is that the figure of our Lord is entirely absent from the scene. For long there had been a gradual lessening of the amount of His figure shown, the cloud taking its place with only the feet and the hem of His garment visible beneath it; but here even this much has vanished, and we have only a cloud, conventionally represented by the curling lines which we noticed before in the Transfiguration scene, resting upon an equally conventional mountain.

The presence of the Virgin in the scene, on our left, was a matter partly of tradition, but still more, says M. Mále, a remnant of the thirteenth-century symbolism in which she represented the Church of Christ 'left on earth to mankind as their guide and support.'

This ends the scriptural series.

Professor E. S. Prior, in his great work, An account of Medieval Sculpture in England, says of the late period to which our subject belongs: 'In the most conspicuous examples of fifteenth-century mason-craft, such as the chapels in royal buildings, the statues in niches alone can pretend to the inspiration of a religious sculpture. The latest style of Gothic building has occupied itself in the mechanism of structure, leaving the Speech of the F aith to the stained glass and the wall painting almost as completely as churchbuilding does this to-day.' Possibly the close proximity of this series of scriptural subjects to the Ship frieze on the Grenewaye chapel escaped Prof. Prior's notice when he took the latter as an illustration ${ }^{1}$ of the non-religious spirit of the church wall-sculpture of the age; for the series we have just seen stands as a somewhat contradictory

1 Chap. xii, section 3, page 520 (fig. 611). 
comment on the passage quoted from him. For here, surely, the Speech of the Faitb is still uttered from stonesculpture, and this series of biblical scenes is manifestly still inspired by the medieval aim of bringing to the eye and understanding of the unlettered certain essential facts of the gospel story. Perhaps the 'Speech of the Faith' in sculpture lingered longer in the west country than elsewhere, though on the other hand it must not be overlooked that there are many evidences in this same district of a specially early response to the influences of the Renaissance. This will be realised when we turn, as we will now proceed to do, to some of the other subjects with which these same walls are decorated. That the two occur close together in the same piece of work is interesting as marking the union-or, more truly, the concurrence-of the religious spirit of Gothic church-sculpture and the pagan spirit of the Renaissance.

Though perhaps scarcely 'pagan' the rest of the subjects taken for the enrichment of the Grenewaye chapel and south aisle are, with a few exceptions, frankly secular; and the Renaissance influence is traceable, not so much in the forms adopted (which continue to be very Gothic in character) as in the introduction of what Prof. Prior calls 'subjects of homely interest,' and these (to quote Prof. Prior again) ' are interesting as giving a hint in the external architecture of England that motives were coming in from the practice of the Renaissance masons such as would mitigate in country practice the formality of Perpendicular ornament.'

Certainly all such formality is absent from the series of ships next illustrated, which form a conspicuous frieze on the south face of the Grenewaye chapel immediately below the string-course on which the scriptural groups are carved.

The selection of these ships as a subject for the decoration of his chapel is undoubtedly due to the fact that John Grenewaye was a prosperous wool-merchant and a member of the Merchant Adventurers' company ; and it was by his work in this line of life that he won the wealth which enabled him to make provision for his own soul in the future, and for the bodies of his poorer neighbours in the present, by building this chapel and a substantial group of alms- 
houses in Tiverton. To him, the armed merchantman and the swift galley were the heaven-blessed means by which he had attained his worldly prosperity ; and therefore they appear on these sacred walls as a sort of consecration of his life-work and a recognition of its relation to higher powers.

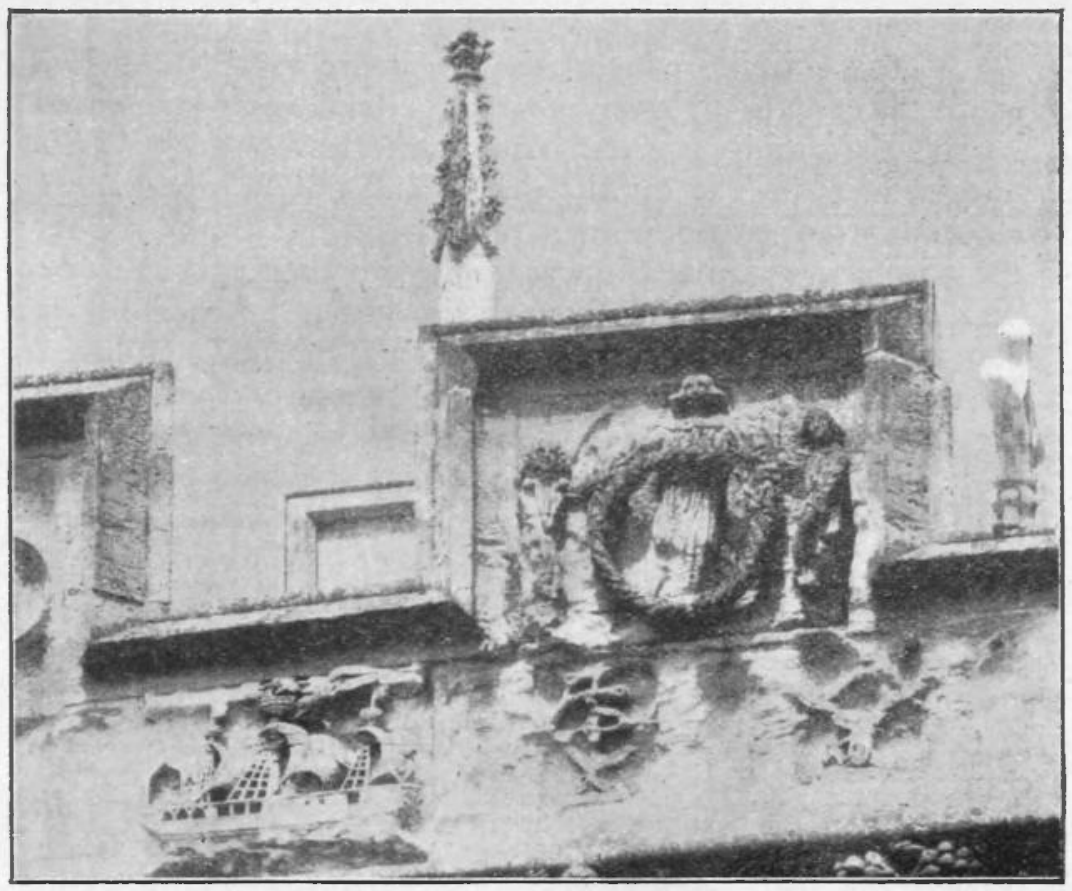

FIG. 2. GRENEWAYE CHAPEL: PART OF THE SHIP FRIEZE.

The theory that has been suggested that these ships represent the Spanish Armada is, of course, absolutely condemned by the fact that these carvings were executed some seventy years before the time of the threatened Spanish invasion.

In examining the frieze of ships (fig. 2, plates viII, Ix) we should specially observe that these carvings are almost unique in giving us not merely correct models of the vessels of the period, but in also showing us very vividly the whole life of the early sixteenth-century merchant service. The eight 
vessels carved on the buttresses of the Lane chapel at Cullompton a few years later, although originally very interesting types of early sixteenth-century vessels, are but sparsely manned and do not exhibit much life and activity among their crews. They are also in a deplorable state of decay. But here we have, with three distinct types of vessels, the fullest details of their rigs and armament, and their crews actively at work.

At the extreme ends of the frieze are represented two small three-decked, twelve-oared galleys, with six seated oarsmen straining at their oars on the lowest deck; guns and gunners on the middle deck; and on the upper deck a company of crossbow-men in action (plate $\mathrm{Ix}, \mathrm{I}$ ). That the rowers are visible from without, and even appear to be on a platform projecting from the lower part of the hull, we can only suppose to be the conventional method employed by the sculptor for revealing to the spectator the internal arrangements of the vessel (something after the manner of an architectural drawing of a building in which part is in section and part in elevation). For, in reality, the oarsmen always worked the great oars, or sweeps, from covered-in decks, or galleries, unseen from without.

The crossbow-men have almost disappeared from the other specimen of the galley, but it retains its armed poop (or raised stern-deck), which in the former one had been destroyed by decay. Both these galleys are beneath a kind of battlemented parapet, which seems to have no connexion with them, unless it is to suggest that they started on their voyages from beneath the fortifications of Tiverton castle!

The pair of fully rigged armed merchantmen, or galliasses, of the sixteenth century, that occupy the centre of each bay of the frieze, are most interesting specimens of that period, and not by any means identical in all details (plate viII). Both are square-rigged, and carry many guns; the western one apparently twelve. She is evidently just starting on a voyage, with all sail set and already feeling the breeze, while the seamen in the 'waist' are in the act of hauling up the bow anchor and making it fast on the starboard bow. Each of the three masts is topped by a large crows'-nest, or rather a 'fighting-top', which in those days was a very essential part of the fighting equipment 
of a ship; some of the men in them are clearly visible, and the large objects projecting from them on either side are the bundles of spears, with which, with other weapons, the 'tops'-men assailed their foes. They are greatly exaggerated in size in these carvings, but their characteristic barbed lance-heads can be easily distinguished. The mainmast flag bears the cross of St. George, at that time the national flag of England. I think the conspicuous white cross at the top of the mainmast is a somewhat ignorant bit of repair-work.

The other (the eastern) of the pair of large ships shows us the end of a prosperous voyage, as in the last we saw the beginning. The sails are furled, the anchor let go, and the work of unloading the merchandise is busily going on. A huge bale, doubtless of John Grenewaye's wool, is being lowered by seamen over the side into a small row-boat made fast under the starboard bow; and two men who have descended into this boat by the ladder slung out over the side are receiving the bale with upstretched arms, while another fat bale is already stowed in the bottom of the boat. Another man is seen in the ratlins in the act of running up the main shrouds to perform some duty aloft.

The third type of vessel represented is a large armed galley, known contemporaneously as a rambarge, or pinnace, using both sails and sweeps as means of progression (plate IX, 2). Ships of this class-intermediate between the small rowed galleys and the large sailing shipswere much longer in proportion to their beam than other vessels, and the rapidity of movement thus possible to them, made them very efficient as fighting vessels. They carried several guns on the middle deck, and 'fighting-tops' on every mast; and in the reign of Henry VIII the English were renowned for their skill in handling these craft. They seem sometimes to have had specially lofty and decorative poops. Both these rambarges, like the smaller galleys, are surmounted by a detached portion of battlemented parapet.

It seems probable that all these ships were carved on blocks of stone in the workshop and inserted afterwards into the masonry of the wall-not carved on projecting blocks left in the masonry for the purpose; this is suggested by the fact that the wave-lines beneath each ship do not 


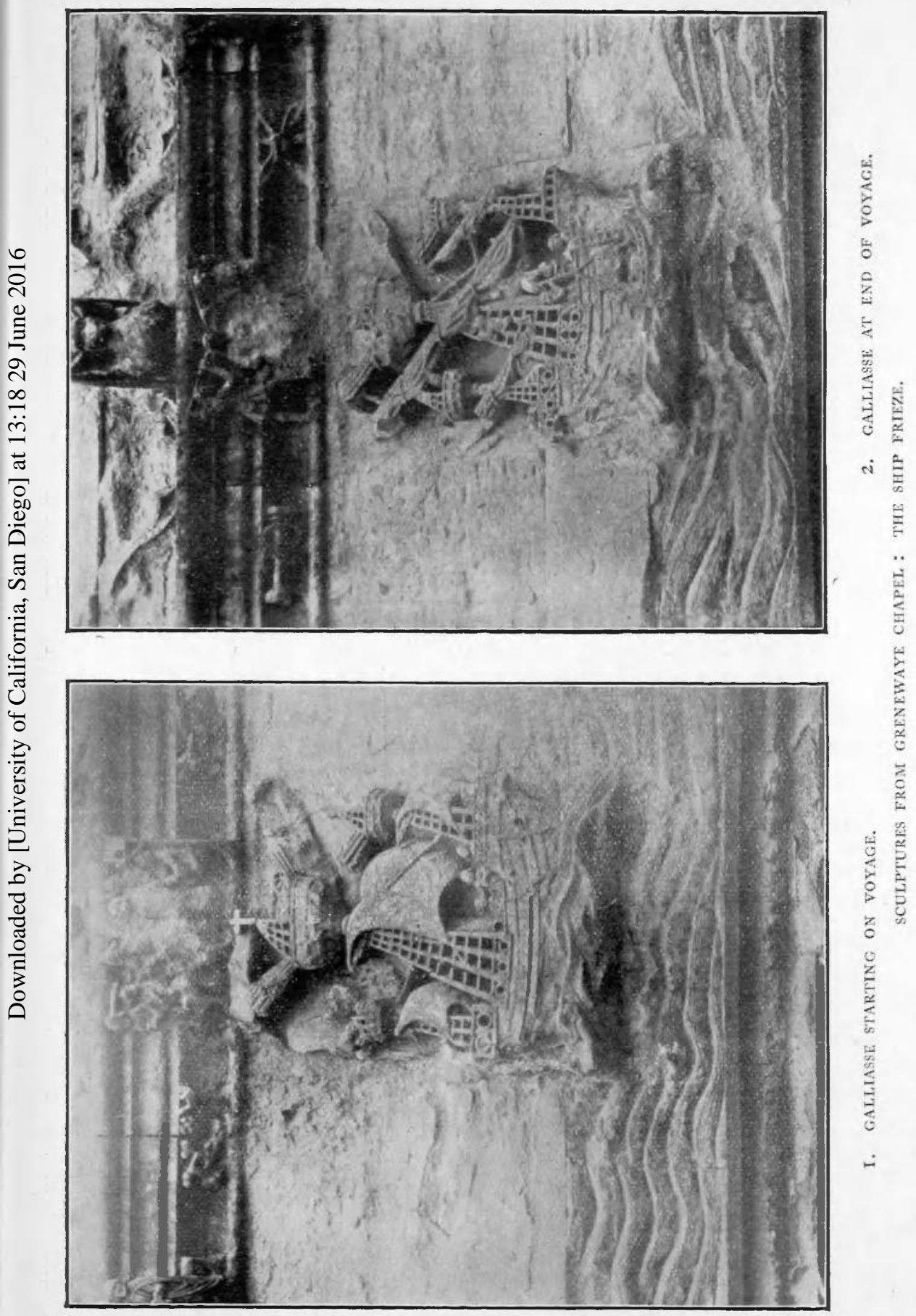




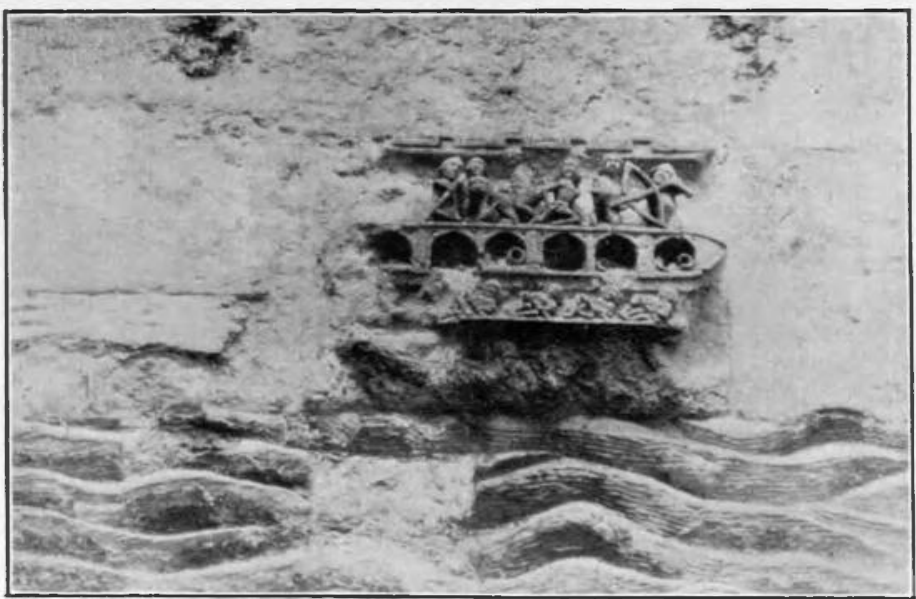

I. THE SHIP FRIEZE : SMALL GALLEY.

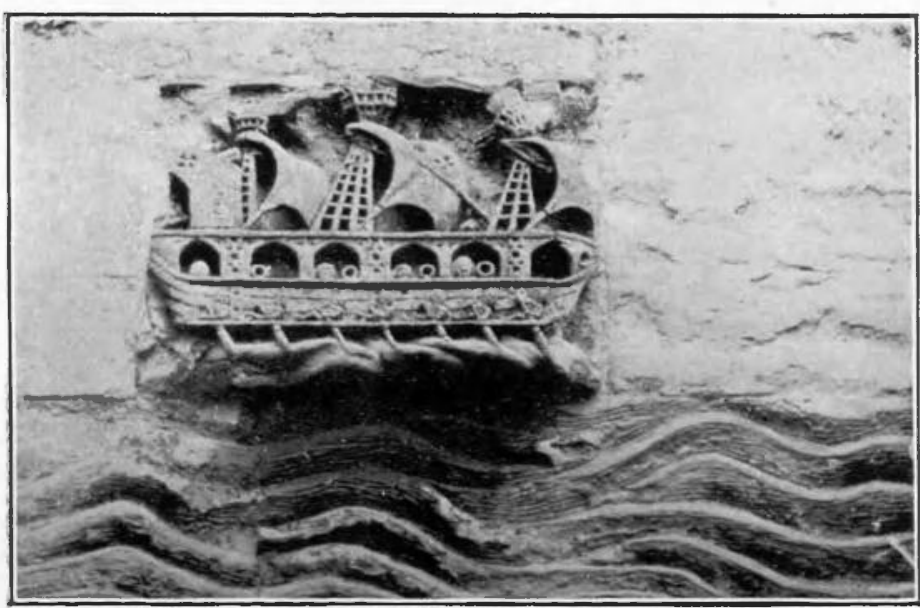

2. THE SHIP FRIEZE : RAMBARGE.

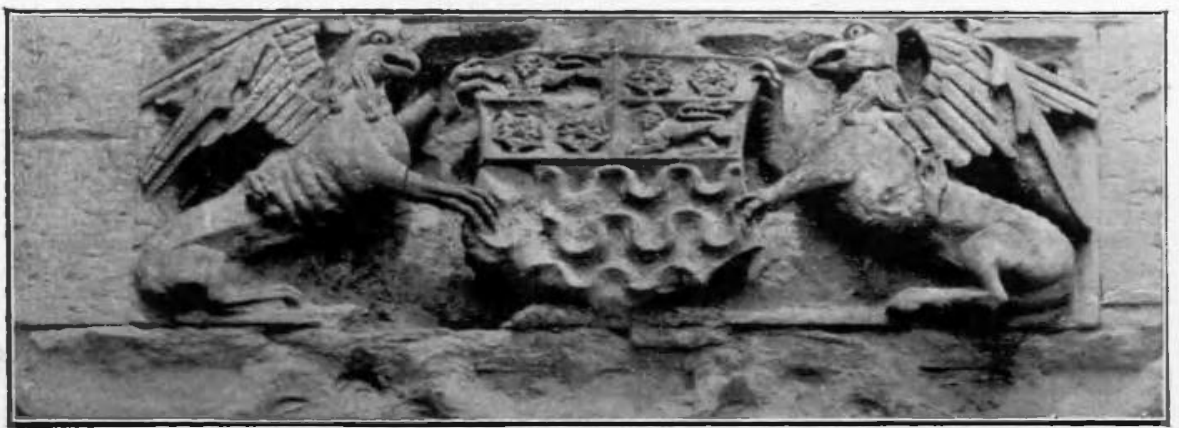

3. ARMS OF MERCHANT VENTURERS' COMPANY. 
fit in with the long continuous wave-lines that are cut in the rest of the masonry of the frieze. However, it is also possible that this continuous undulatory masonry has been renewed in the course of repairs, and the shipcarvings cut out in blocks from the old work, and that when these were reinserted, no great care was taken to fit the one to the other.

Ships are carved on other portions of Grenewaye's work, one on each of the sixteen buttresses of the chapel and south aisle and two on the parapet of the south aisle. There is a considerable variety in their detail, but space will not allow of our illustrating any further examples; but even with the few ships illustrated from the whole twenty-four we are taken into the very heart of the life of the merchant service of the early sixteenth century-such an absolutely essential factor in the trade by which John Grenewaye gained his wealth.

The Merchant Venturers' company of England, to which he belonged, was a trading corporation of very early origin and much wealth and importance. As a society it was incorporated in the reign of Edward I (1296). Its shield of arms, blazoned by Mr. Fox-Davies as 'Barry nebulee of six argent and azure, a chief quarterly gules and or, in the first and fourth quarters a lion passant guardant of the fourth, in the second and third two roses gules barbed vert,' is carved only once on the chapel, in the highest frieze just below the pierced parapet (plate Ix, 3), but it also appeared on the brass which covered the founder's vault within.

Besides this important connexion, John Grenewaye was also a member of the Drapers' company, which was one of the most important of the twelve great London companies. They, with the Mercers, had been the chief of the trading companies of London ever since the fourteenth century, when Edward III, in 1364, gave them their first grant; but their charter of incorporation dates from I 439 and was given them by Henry VI when their armorial bearings were also granted to them. These arms, which appear in numerous parts of the chapel, are here represented according to the usual blazon, viz. :--'Azure, three clouds radiated in base proper, each adorned with a triple crown (or papal tiara) or' (plate $\mathrm{x}, \mathrm{I}$ ). But on the visit to 
Tiverton of the Royal Archaeological Institute, in I9I3, Sir William Hope drew attention to this as an error, and said that the proper explanation of the arms was to be found in the English custom of preserving the Sacrament over the altar in a hanging pyx (or small casket) with a veil, or ' pyx-cloth,' over it ; and the Drapers' company adopted for their arms three pyx-canopies with the linen veils, which last item they supplied. The so-called clouds and radiations were originally the ends of the pyx-cloths hanging down.

The business of this company included the supervision of the traffic in the finished goods of the woollen trade.

All these business connexions of John Grenewaye are given an important place in the carvings of his chapel, especially on the panels of the uppermost frieze, where also his own arms occur several times. These are blazoned as 'Gules, a chevron between three covered cups or, on a chief of the second three griffins' heads erased azure' (plate $\mathrm{x}, 2$ ).

This whole frieze, though much weather-worn, is worth study, consisting as it does of two heraldic shields in each bay supported by either animals or angels; but we must pass on now to some other points, only just pausing to glance at one bay of the richly pierced parapet which crowns the whole of the chapel walls.

The south aisle also has a battlemented parapet, unpierced, but crowded with most interesting detail, as is also the string-course immediately below it. One specimen only must now detain us. It shows a group consisting of three angels, supporting a large wreath or torse surmounted by a cross patee; the only probable explanation of this torse seems to be that it is an extremely conventional representation of the Crown of Thorns, but the remarkable thing about it is that none of the other emblems of the Passion occur on any of the rest of the battlements; they bear nothing more important than flowers, quatrefoils, or monograms.

Space will not allow of our illustrating more than a few of the remaining details from the exterior of the chapel, and these are selected from the buttresses where various subjects, besides the ships already mentioned, are carved. The most important of these are the four seated figures 


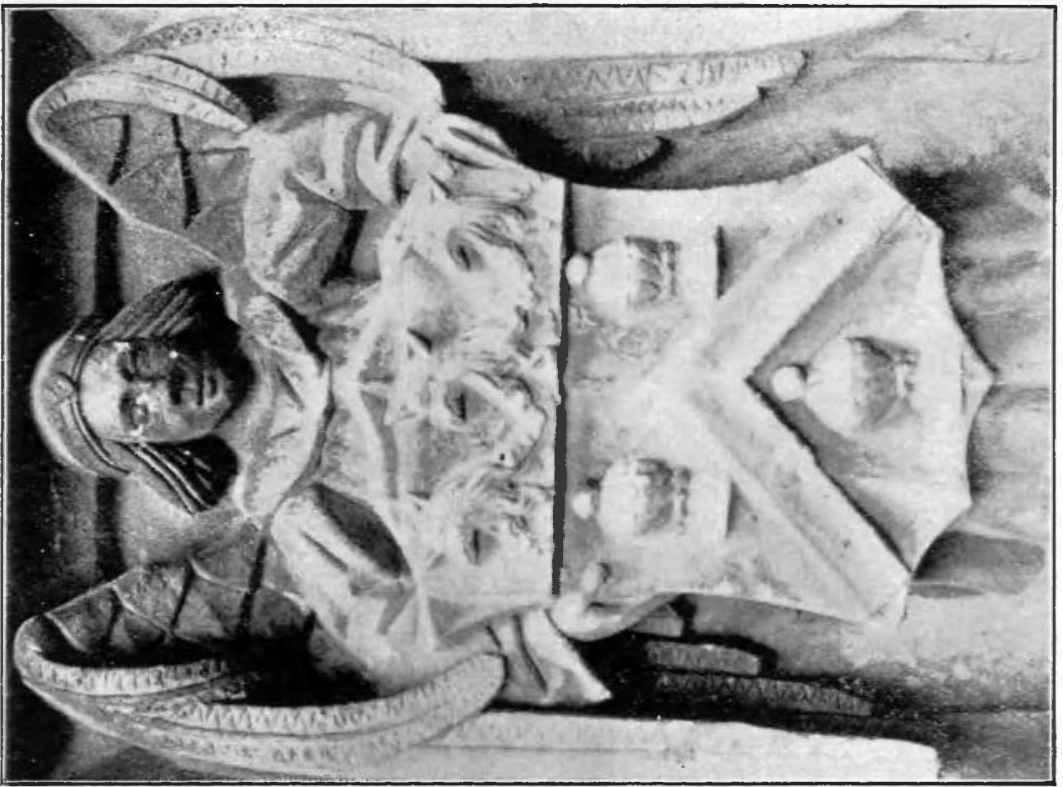

告

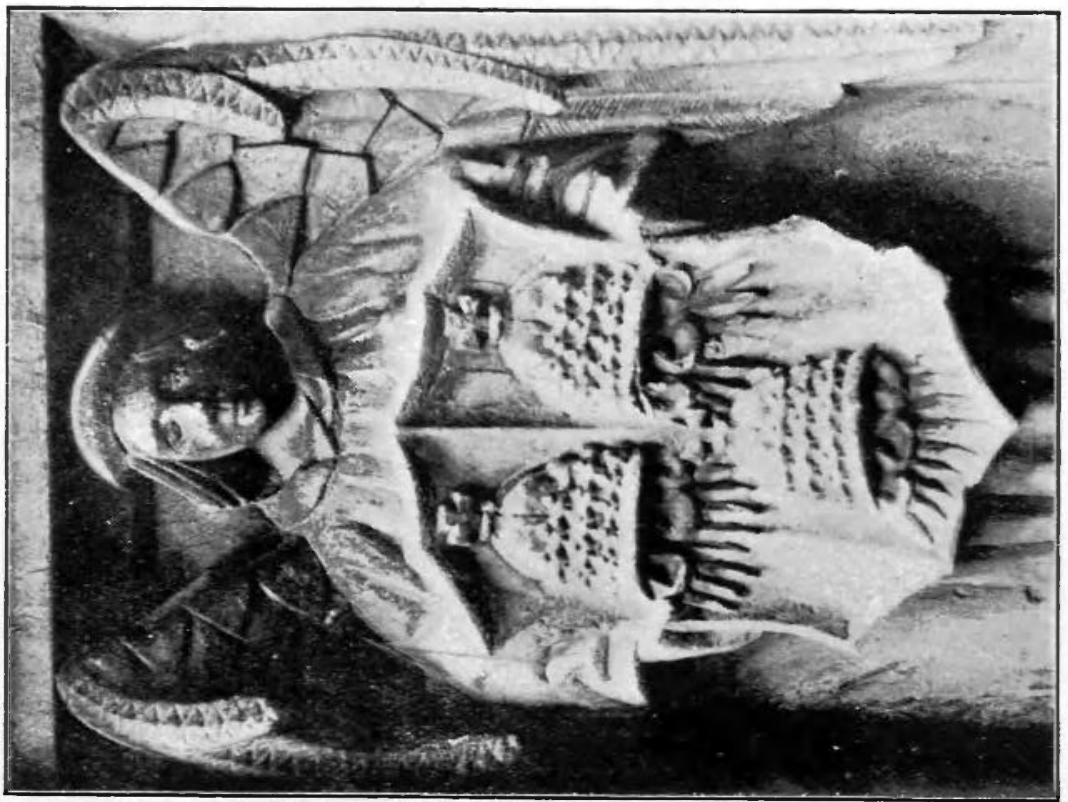




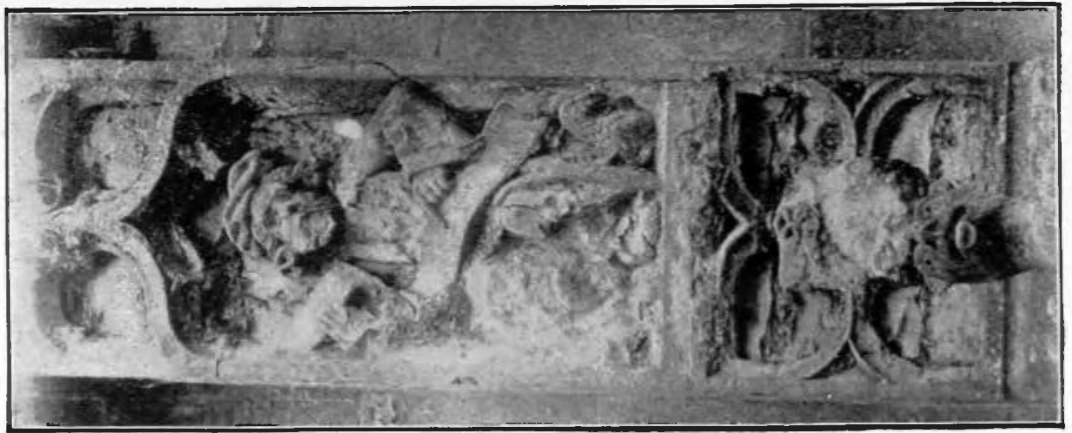

$\frac{1}{0}$

ثึ

$+$

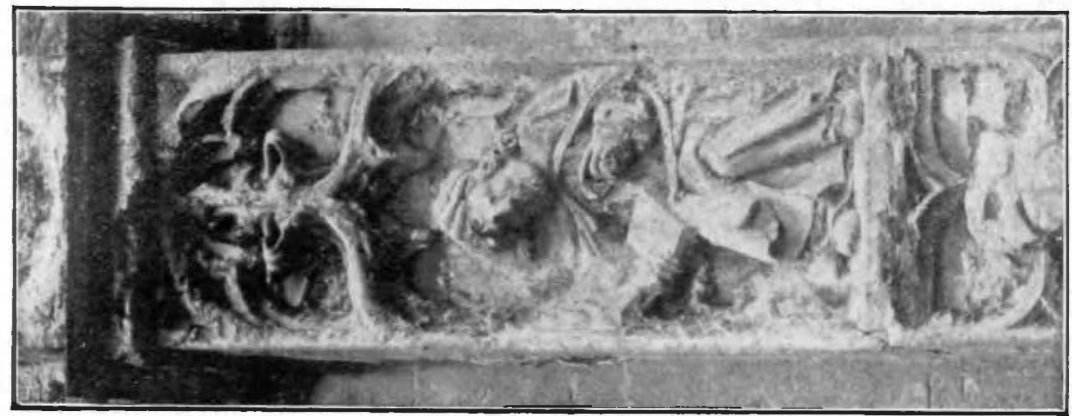

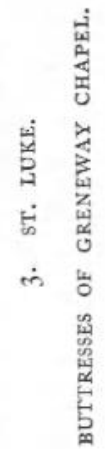

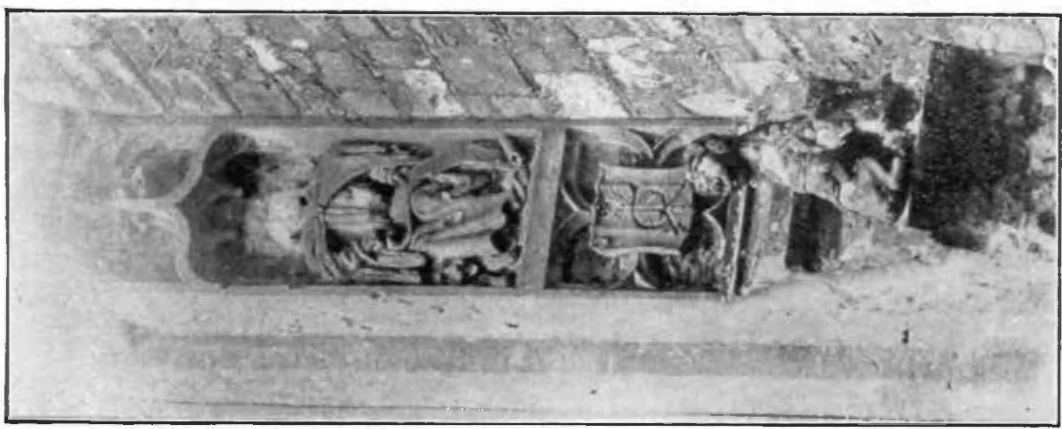

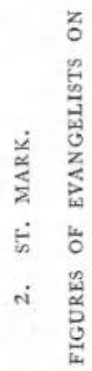

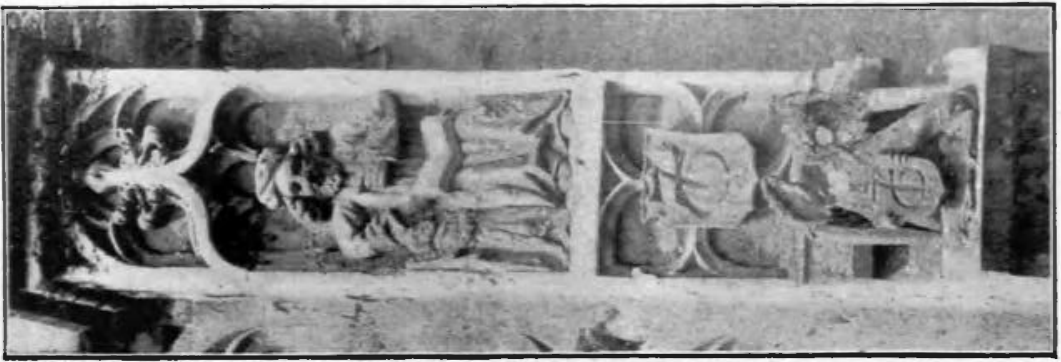

葢 
of the evangelists on the panels of the eastern and southeastern buttresses (plate xI). In the History of Tiverton Church by Mr. Chalk, already referred to, these are erroneously described as 'John Grenewaye engaged in various occupations, on his head a kind of turban'!but even in their present state of mutilation there are left the clear indications of their identity and emblems.

St. Mark occupies the north-eastern buttress, his scroll upon his knees, and the lion, his emblem (described as ' a human-faced dog ') by his side. St. Matthew follows on the next eastern buttress with his emblem, the angel, standing at his knee, on which the open book of his Gospel rests, while his left hand is raised with extended fore-finger in the conventional medieval manner of indicating a teacher. This feature will be observed in each of the figures.

On the easternmost buttress on the south, St. John is represented, evidently expounding his Gospel from a large open scroll; on the ground, on his left, is the eagle, his emblem. Like St. Matthew, he wears a turban and robe, the medieval ideal of oriental dress, though usually the turban is specially associated with representations of the prophets, and not of the evangelists.

Although the bull (or calf), St. Luke's emblem, has entirely disappeared from the next panel, there can be no doubt as to the identity of the figure, who is likewise expounding from his Gospel, which is shown, like that of St. Matthew, not as a scroll but as a bound book.

On the four buttresses of the porch there have been four other human figures in similar panels; but the three original ones that are left are in a hopelessly decayed condition and not easy to identify. The few definite indications that remained in I9I4 pointed, however, to there being a second representation of the evangelists. These remnants of detail are now also destroyed by the recent cleaning. Besides these buman figures the buttresses are decorated with many specimens of animal life, not only in conventionally heraldic forms (of which there are innumerable instances), but also more naturally portrayed. An ape with its child is about the best preserved of these. In the Bestiaries-those quaint medieval cyclopedias of unnatural history - the ape is said to carry those of its young 
'whom it loves most dear' before it, and those whom it hates on its back, especially when fleeing from the hunter; and is therein likened to the Devil, who (so says an early twelfth-century Bestiary) ' misleads him who will serve him, and will place him before him in hell where he will go, and will leave at his back the good men whom he will hate' 1 There is probably a recollection of this tradition in the Tiverton pair. The ape generally in medieval sculpture symbolises fraud and indecorum.

The rest of the decoration of the buttresses, both on the chapel and the south aisle, consists, besides the ships already mentioned, of Grenewaye's merchant's mark (very often repeated), anchors, wool-packs, and the J. G. monogram over and over again (plate XII); and on the off-sets various heraldic beasts--lions, leopards, dogs, etc. holding shields (fig 3 ).

It is obvious that the chapel buttresses have undergone much repair : their base-courses, and as far above as up to the lowest off-set being almost entirely refaced. In some instances even the original sculptures have been replaced by modern copies, probably in the general restoration of the chapel and porch in 1829 , when, however, the carvings apparently were on the whole carefully dealt with and preserved as far as possible.

A few moments must be given to the porch which adjoins the western face of the chapel (plate XIII, I), and indeed it deserves much longer study.

It has undergone more than one drastic restoration, ${ }^{2}$ but in many cases the original work has been incorporated with the new, especially as regards the sculptures. Most noteworthy among these is the central panel over the outer doorway. Within a niche flanked by pillars, decorated with plain and beaded spiral bands and carrying an ogee arch, is a large shield charged with the arms of the widowed Katherine Courtenay, countess of Devon, who was youngest daughter of Edward IV, sister-in-law of Henry VII, and aunt of Henry VIII, and was resident at Tiverton castle at the time of John Grenewaye's additions to the

\footnotetext{
I For these quotations and references I am indebted to Mr. G. C. Druce, who kindly looked them out for me in the British Museum.
} plete recarving of the external frieze in the early years of this century. 


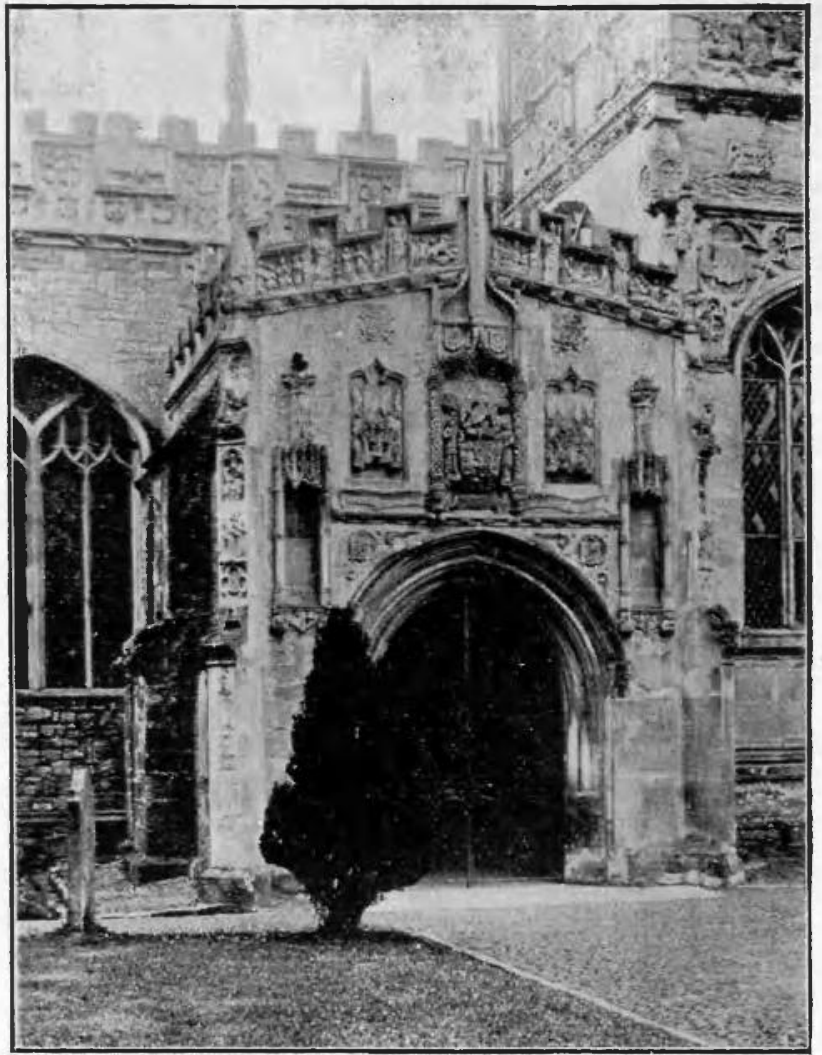

TIVERTON CHURCH : SOUTH PORCH. I. VIEW FROM S.

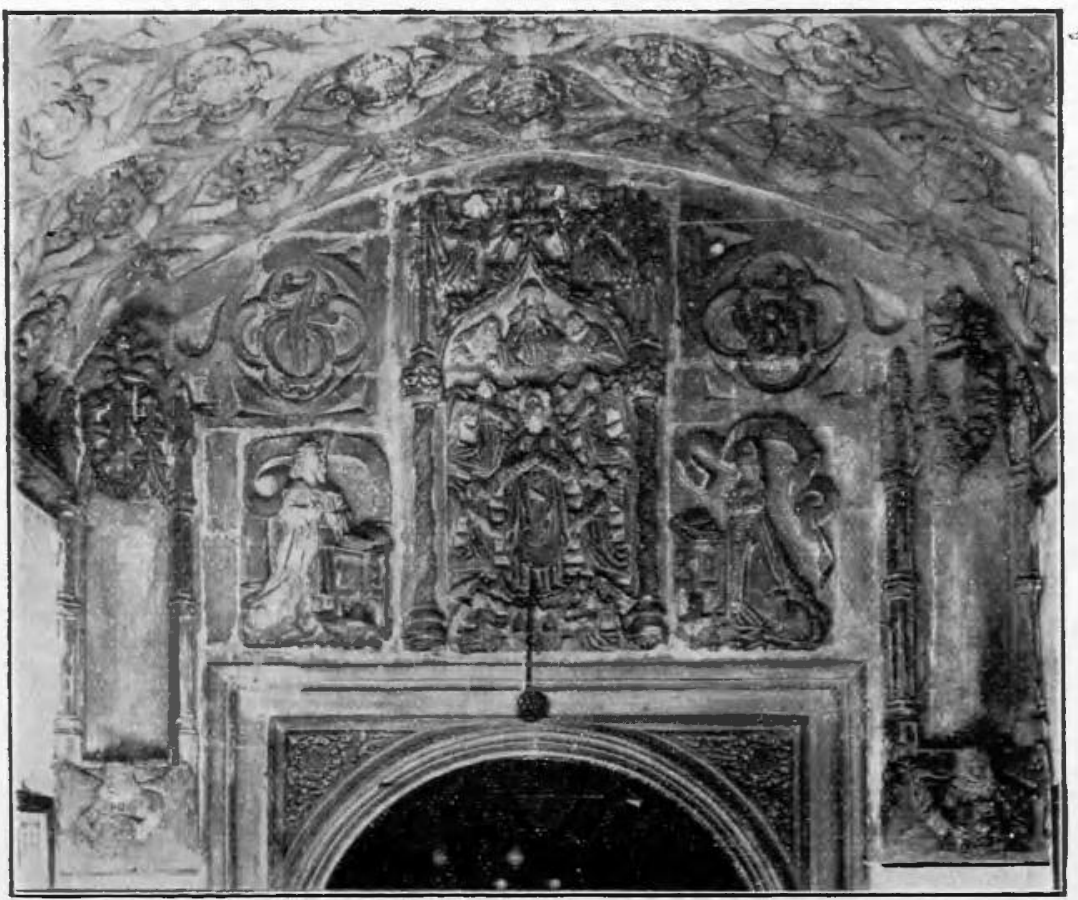

2. SCULPTURE OVER INNER DOORWAY. 
church. The arms are the same as those on her seal, viz. : quarterly $\mathrm{I}$ and 4 , or, 3 torteaux (for Courtenay); 2 and 3, or, a lion rampant azure (for Redvers); impaling

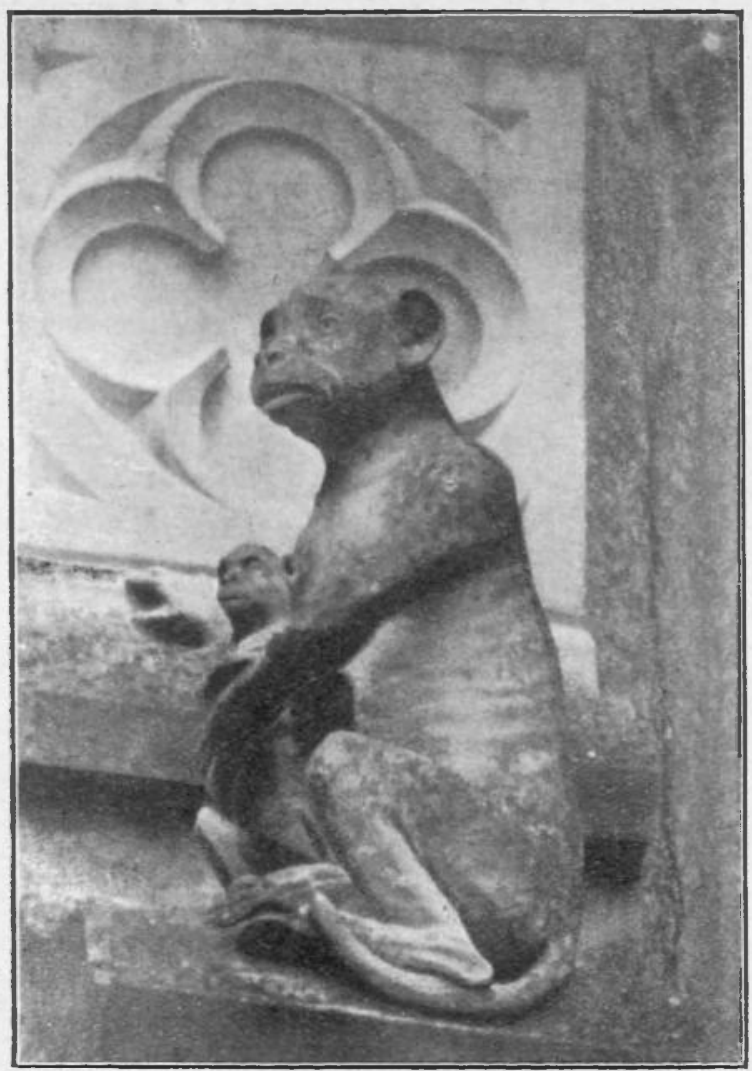

FIG. 3. SCULPTURES FROM GRENEWAYE CHAPEL:

FIGURE OF APE.

quarterly, I, France and England quarterly ; 2 and 3, or, a plain cross gules (for earls of Ulster); 4, Barry of six or and azure, on a chief of the first 3 pallets between 2 gyronne of the second ; over all an escutcheon ermine (for Mortimer, earl of March). But, whereas on the seal the supporters are dexter, a dolphin, and sinister, the lion of March, 
here they are dexter, a knight in armour treading on a dragon, and sinister, a woman.

Above is an eagle rising from a faggot of sticks, one of the badges used by the Courtenays of Tiverton.

The sculptured frieze running along the gable just under the battlements is all very recent work.

Quite new is also the scroll with its inscription which runs above the head of the doorway; but it is supposed to reproduce the original. The legend is : In tyme and space God send grace John Greneway to performe $\mathrm{Y}^{\mathrm{t}} \mathrm{y}^{\mathrm{r}}$ hate be gone.'

I am strongly inclined to think that a radical mistake has been made in the carving of the last five words, either originally or in the reproduction; and that they should run :- ' $\gamma^{i} \gamma^{i}$ batb (i.e. " he hath," contracted) begun'; which would make far better sense than the present version. A muddle in the abbreviations and spelling of the words of this phrase might easily have been made by the original carver.

Inside the porch, and over the inner doorway, are the carvings shown in plate xIII, 2, which represent the Assumption of the Virgin in the centre panel, and in the two side panels John and Joan Grenewaye kneeling at fald-stools in worship.

The carved stone barrel-vault of the porch (plate XIv, I) is covered with a variety of devices, amongst which are seen a ship, several anchors, the eagle on the faggot, wool-packs, Grenewaye's merchant's mark and monogram, two birds back to back, flying fish, a griffin holding a shield, amphisbaenae, and other grotesques, besides floral ornaments.

In the eastern wall of the porch is the doorway leading into Grenewaye's chapel ; and its black oak door is a piece of work of uncommon richness and interest (plate xv, I). It may be of slightly later date than the actual building, but not much so, and it is a very good example of what is seen in much of the woodwork of this period in midDevon, viz. the combination of early Renaissance designs imported from foreign sources, with the long-established, familiar forms of English Gothic work. The head and upper panels are distinctly Gothic in form, although the carving of the cusps shows strong Renaissance influence, 


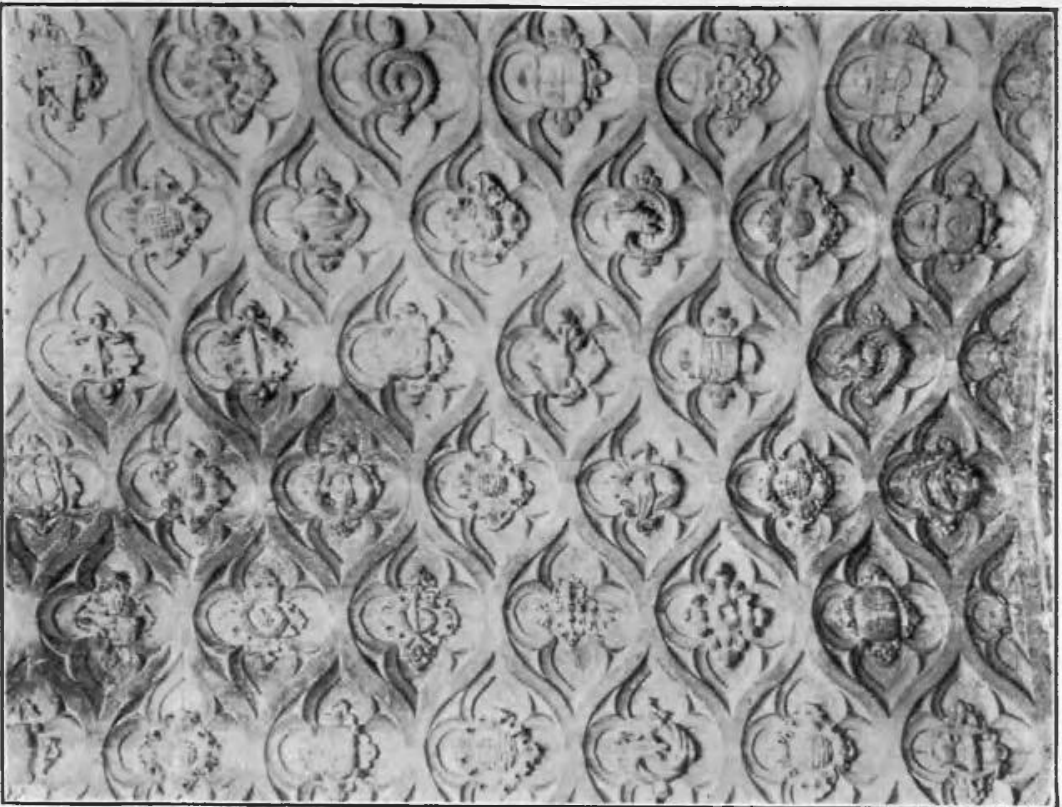

\section{VAULT OF SOUTH PORCH.}

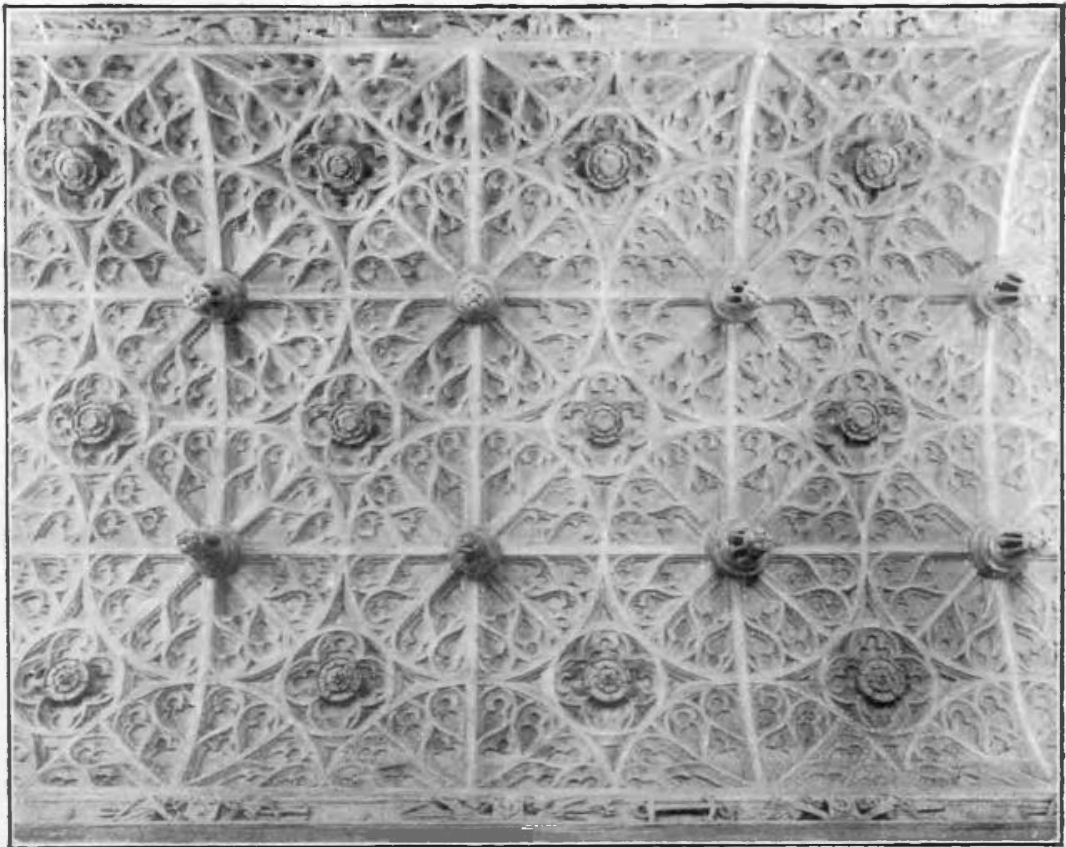

2. VAULT OF GRENEVAYE CHAPEL. 

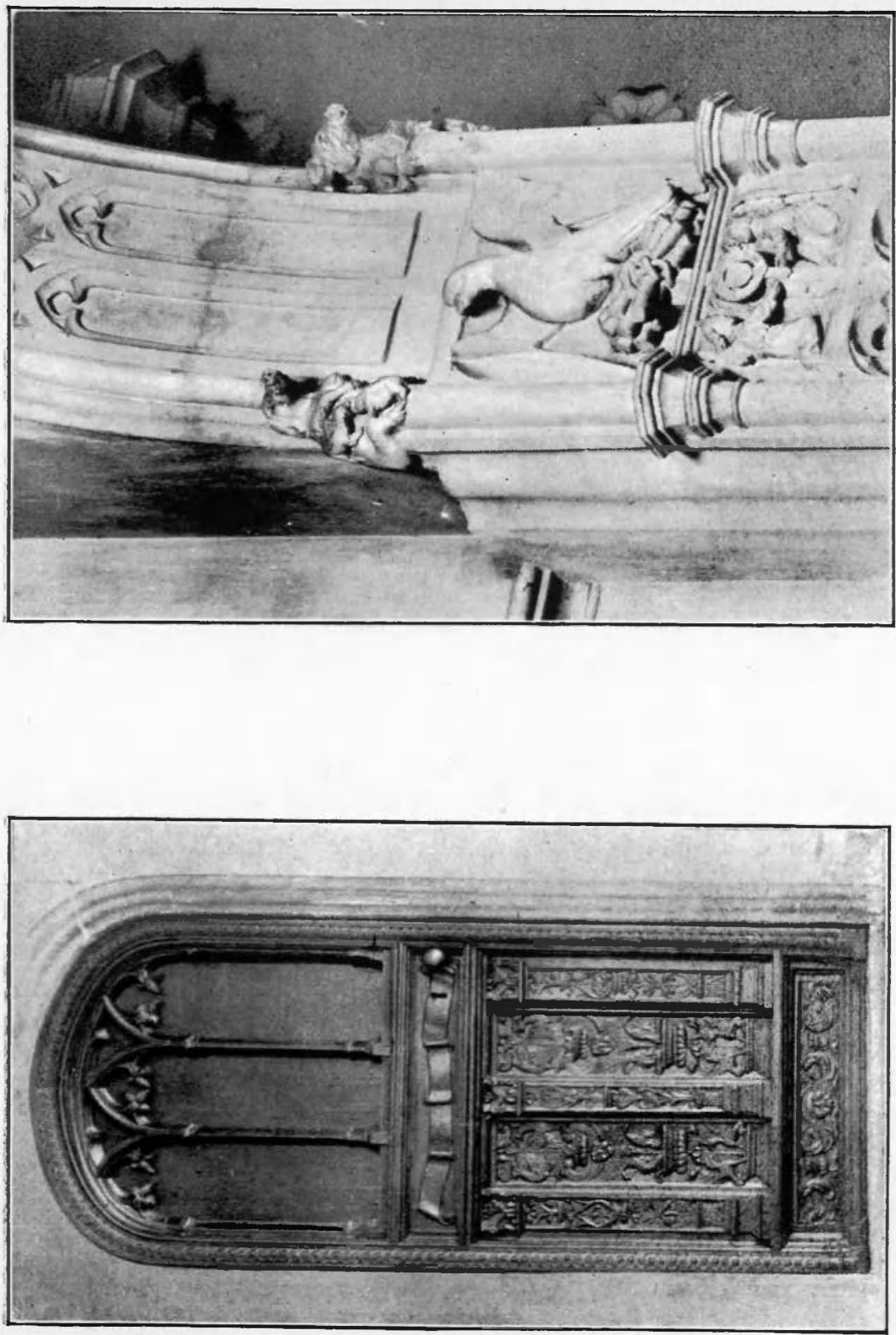
while the lower panels are of very pronounced Renaissance type both in form and detail. ${ }^{2}$ Small portions of the carved moulding which runs round the whole door have had to be renewed, and one patch on the left side of the lower half is conspicuous for the clumsiness with which a copy of the original delicate design has been attempted.

Plate xIv, 2 shows a portion of the ceiling of the Grenewaye chapel. It is not a real fan-vault in construction, such as that of Lane's chapel, Cullompton, or that over the Dorset aisle in Ottery St. Mary church; it is merely a segmental barrel-vault decorated with shallow carvings, with large wooden pendants, whitened over, in like imitation. Mr. Chalk says that these pendants are of plaster, but the master-mason, who has worked on the church for years and repaired this vault, tells me they are merely wood. The whole vault is doubtless a piece of work of one of the chapel restorations.

In 1829 the inside of the chapel was so severely dealt with that its original detail, including the open stone screen separating it from the south aisle, has almost disappeared. The capitals of the piers of the screen-arches remain, and they are small and octagonal in form, of the type we shall see presently in the north chancel arcade.

There are therefore no further illustrations of the interior of the chapel worth giving; but a few of much interest from the body of the church will afford some idea of its character before its radical rebuilding in 1857 .

The piers of the chancel arcade of two bays have not been rebuilt in modern times, but they are of different dates on the north and south; the latter being evidently the earlier. From records showing that, after Bishop Stafford's order in I4I2 for the rebuilding of the chancel, certain lands were given in $\mathbf{1} 420$ to the church for the repair of the fabric, it would seem probable that these piers belong to the first half of the fifteenth century.

Those of the north arcade are obviously a good deal later, and, being similar in form to those belonging to Grenewaye's chapel arcade, may have been part of his work.

\footnotetext{
1 Cf. early sixteenth-century bench ends at Lapford, illustrated in Examples of

Renaissance Cburcb Woodwork in Devon, by E. K. Prideaux (Commin, Exeter, 1910).
} 
The capitals of the piers that carry the chancel arch, where they form the east responds to the nave arcade, are also original and evidently a part of Grenewaye's work, having among their carvings his monogram and merchant's mark, and the arms of the Drapers' company; also the ' sun in splendour,' one of the badges of Edward IV, father of the then resident countess of Devon.

These piers also retain their original canopied niches on the north-west and south-east faces. Angelic demifigures support the brackets of these niches, two of which are very coarse, inferior work, and of a crude type not at all equal to the exterior carvings. And the other two, of a very life-like man and woman with angels' wings, and hands folded in devotion, are well carved modern insertions intended to portray and commemorate John Grenewaye and his wife Joan.

At the spring of the chancel arch, on both north and south sides, is carved the device seen in plate $x v, 2$. It shows the Courtenay badge of the eagle rising from a faggot of sticks, and above, on either side, are pigs seated on the truncated ends of the angle shafts. These should, properly, both be boars, the supporters of the Courtenay shield, but the artist has taken the liberty of substituting on the western side a sow with two piglings.

On a panel below the eagle, and carved on a much smaller scale, are two kneeling angels supporting a shield charged with the Courtenay arms (or, 3 torteaux) within the garter; some of the motto has disappeared through age, but 'qui mal y pense' is still plainly visible. This work too is probably some of Grenewaye's, as the first earl of Devon to be created a knight of the Garter was Edward Courtenay, who received that honour in 1485 and died in 1509, only eight years before Grenewaye's extensive reconstructions in the church were in hand. The chancel arch has apparently never been completed, for the mouldings which were obviously intended to be carried round it, rising from the small capitals at the spring, have been left abruptly cut off, and the arch has a most unfinished look on both its eastern and western faces; but there is no record to explain this state of things.

The carved capitals of the nave piers are part of the work which was standing in the church 


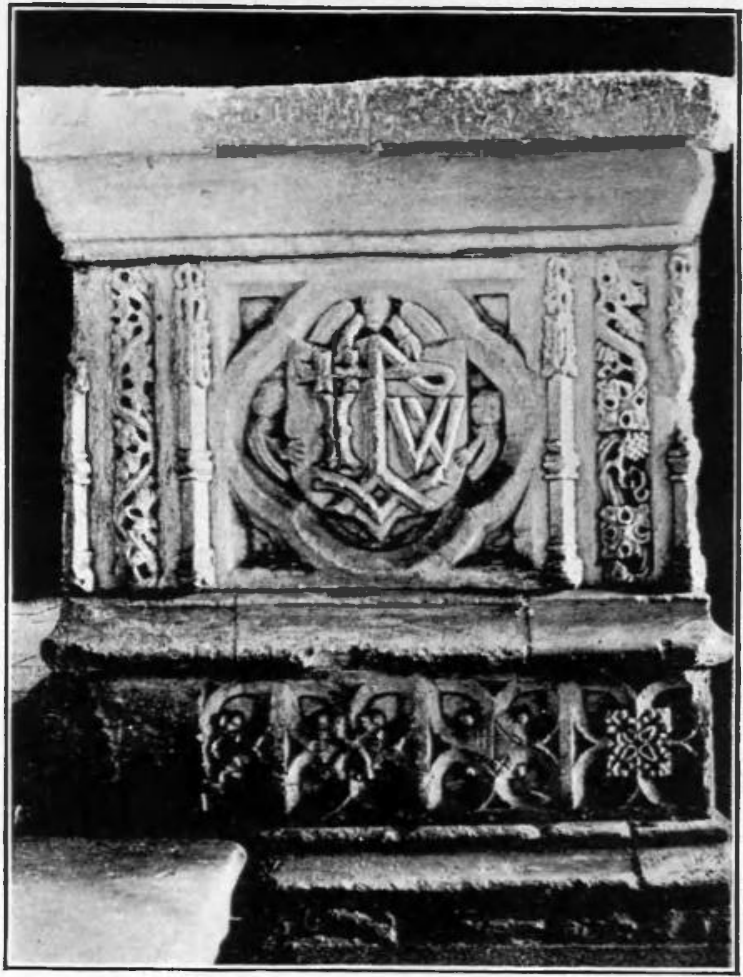

I. JOHN WALROND.

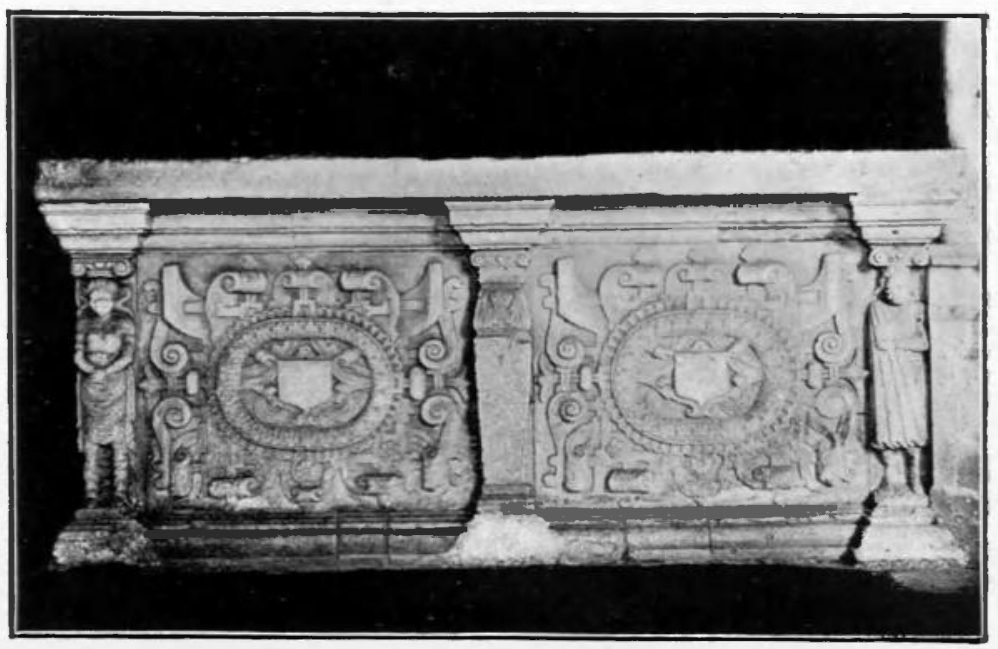

2. GEORGE SLEE.

TIVERTON CHURCH : TOMBS. 
before the nave was rebuilt in 1857 . Happily, they were preserved and reinstated on the new piers. They are not all, apparently, of the same date, but judging from several definite indications and their general style, it would seem probable that they are mainly the work of the early part of the sixteenth century.

Those on the south are certainly part of Grenewaye's rebuilding, many of them showing the four-grooved shield so frequently occurring on his chapel.

The capital, second from the east in the north arcade, has the Courtenay eagle-badge again; and on another face of the same capital occurs a significant, though small, feature, indicating the period of carving as being that when Renaissance detail was just beginning to show itself in decorative sculpture. I refer to the small animal head with which one part of the foliage here terminates.

The two other faces of this capital are repetitions of these two designs.

On the southern pier arcade, one of the westernmost capitals shows still more definite Renaissance influence in the little wingless, seated figures which carry the scroll twining round the capital, and which take the place of the winged and floating angels (all clumsy enough) which in the other similar capitals support the various details of the designs.

Others of the capitals bear monograms, quaint birds and masks among foliage, and such devices as the rose-ensoleil (a badge of Edward IV), the fleur-de-lys (a badge of Henry VII), a ducal crown, and many blank shields. But space will not allow of any more specimens being given.

There are, however, two table-tombs in the chancel which should, perhaps, be recorded in connexion with the late medieval sculptures of the church (plate xvI). The one on the south side, the earlier by thirty-four years, is that of John Walrond (died 1579), and, in spite of the lateness of its date, is still thoroughly Gothic in character.

John Walrond's initials and merchant's mark, and his wife's initials, R. W., form the chief motives in the decoration; but the vine and other foliage appear, and on the western face three very coarse and clumsy supporting 
angels are added to the design. The material of the tomb, including the slab, is Beer stone.

In the work of the northern tomb, also of Beer stone but with a Purbeck marble slab, we have altogether passed away from the late Gothic sculpture with which this paper has been concerned; but yet it may be allowed to appear, if only to illustrate how, in the thirty-four years between the date of the last tomb and the death, in I6I3, of George Slee commemorated here, Gothic feeling and style had absolutely vanished before the fashion for pseudo-classic designs and details.

$\AA$ wider step could hardly be found than that taken from the late Gothic scriptural groups with which our illustrations began, to this most characteristic specimen of Jacobean work, though scarcely one hundred years divides them.

And although there are many more details worth recording, enough has now been shown, I hope, to justify my opening remark as to the late survival, in this west-country church, of the Gotbic spirit of religious art, though mingled with the more secular and realistic details characteristic of the age in which they were executed. 